\title{
New Knowledge on the Performance of Supercritical Brayton Cycle with $\mathrm{CO}_{2}$-Based Mixtures
}

\author{
Aofang Yu ${ }^{1}$, Wen Su ${ }^{1} * * \mathbb{C}$, Li Zhao $^{2}$, Xinxing $\operatorname{Lin}^{3}$ and Naijun Zhou ${ }^{1}$ \\ 1 School of Energy Science and Engineering, Central South University, Changsha 410083, China; \\ yuaf923@csu.edu.cn (A.Y.); njzhou@csu.edu.cn (N.Z.) \\ 2 Key Laboratory of Efficient Utilization of Low and Medium Grade Energy (Tianjin University), MOE, \\ Tianjin 300072, China; jons@tju.edu.cn \\ 3 Institute of Science and Technology, China Three Gorges Corporation, Beijing 100038, China; \\ lin_xinxing@ctg.com.cn \\ * Correspondence: suwenzn@csu.edu.cn; Tel.: +86-0731-8887-9863
}

Received: 24 February 2020; Accepted: 1 April 2020; Published: 5 April 2020

\begin{abstract}
As one of the promising technologies to meet the increasing demand for electricity, supercritical $\mathrm{CO}_{2}\left(\mathrm{~S}_{-} \mathrm{CO}_{2}\right)$ Brayton cycle has the characteristics of high efficiency, economic structure, and compact turbomachinery. These characteristics are closely related to the thermodynamic properties of working fluid. When $\mathrm{CO}_{2}$ is mixed with other gas, cycle parameters are determined by the constituent and the mass fraction of $\mathrm{CO}_{2}$. Therefore, in this contribution, a thermodynamic model is developed and validated for the recompression cycle. Seven types of $\mathrm{CO}_{2}$-based mixtures, namely $\mathrm{CO}_{2}-\mathrm{Xe}, \mathrm{CO}_{2}-\mathrm{Kr}, \mathrm{CO}_{2}-\mathrm{O}_{2}, \mathrm{CO}_{2}-\mathrm{Ar}, \mathrm{CO}_{2}-\mathrm{N}_{2}, \mathrm{CO}_{2}-\mathrm{Ne}$, and $\mathrm{CO}_{2}-\mathrm{He}$, are employed. At different $\mathrm{CO}_{2}$ mass fractions, cycle parameters are determined under a fixed compressor inlet temperature, based on the maximization of cycle efficiency. Cycle performance and recuperators' parameters are comprehensively compared for different $\mathrm{CO}_{2}$-based mixtures. Furthermore, in order to investigate the effect of compressor inlet temperature, cycle parameters of $\mathrm{CO}_{2}-\mathrm{N}_{2}$ are obtained under four different temperatures. From the obtained results, it can be concluded that, as the mass fraction of $\mathrm{CO}_{2}$ increases, different mixtures show different variations of cycle performance and recuperators' parameters. In generally, the performance order of mixtures coincides with the descending or ascending order of corresponding critical temperatures. Performance curves of these considered mixtures locate between the curves of $\mathrm{CO}_{2}-\mathrm{Xe}$ and $\mathrm{CO}_{2}-\mathrm{He}$. Meanwhile, the curves of $\mathrm{CO}_{2}-\mathrm{O}_{2}$ and $\mathrm{CO}_{2}-\mathrm{N}_{2}$ are always closed to each other at high $\mathrm{CO}_{2}$ mass fractions. In addition, with the increase of compressor inlet temperature, cycle performance decreases, and more heat transfer occurs in the recuperators.
\end{abstract}

Keywords: supercritical Brayton cycle; $\mathrm{CO}_{2}$-based mixture; thermodynamic performance; compressor inlet temperature

\section{Introduction}

\subsection{Background}

According to the BP (British Petroleum) Statistical Review of World Energy 2019, global energy demand grew by $2.9 \%$ and carbon emissions grew by $2.0 \%$ in 2018 . With energy demand and carbon emissions growing at their fastest rate for years, there is a growing mismatch between societal demands for action on climate change and the actual pace of progress [1]. Therefore, the need to develop renewable energy and improve the energy conversion efficiency is urgent. As one of the most promising candidates that can potentially replace the steam Rankine cycle, the supercritical 
$\mathrm{CO}_{2}\left(\mathrm{~S}-\mathrm{CO}_{2}\right)$ power cycle has the advantage of high efficiency, economic structure, and compact turbomachinery. This is because $\mathrm{CO}_{2}$ has the low critical temperature $\left(T_{c 0}=304.13 \mathrm{~K}\right)$ and moderate pressure $\left(P_{c 0}=7.38 \mathrm{MPa}\right)$, so that the compressor work can be greatly reduced when operating around the critical point. Furthermore, due to the fact that the inert gas $\mathrm{S}-\mathrm{CO}_{2}$ is compatible with structural materials, the $\mathrm{S}-\mathrm{CO}_{2}$ cycle has the potential to achieve a higher turbine inlet temperature [2]. Today, the $\mathrm{S}-\mathrm{CO}_{2}$ cycle has been widely applied in various energy sources, such as nuclear energy, solar energy, geothermal energy, and waste heat utilization [3-7]. Much effort has been paid to conduct the theoretical modeling on the thermodynamic processes and the performance comparison of different cycle layouts based on the property characteristics of $\mathrm{S}-\mathrm{CO}_{2}[8,9]$.

\subsection{Cycle Layouts and Performance Comparison}

In order to improve the cycle efficiency and alleviate the temperature mismatch in the heat exchanger, many advanced S- $\mathrm{CO}_{2}$ cycle layouts such as simple recuperation cycle, recompression cycle and partial cooling cycle have been proposed, based on the original configuration of Brayton cycle [10]. For the recuperation cycle, a recuperator is introduced to recover the exhaust heat of $\mathrm{S}-\mathrm{CO}_{2}$ at the low-pressure side. Although the recuperation cycle can improve the efficiency greatly, it still suffers the temperature pinch-point problem in the recuperator, which is caused by the huge difference in the heat capacity between the hot and cold sides of the recuperator. Thus, the recompression cycle divides the recuperator into the high-temperature recuperator (HTR) and the low-temperature recuperator (LTR) and reduces the difference of heat capacity in LTR by splitting the flow stream of S-CO $\mathrm{CO}_{2}$ at the inlet of gas-cooler [11]. For the partial cooling cycle, it is generally derived from the recompression cycle. The flow stream is usually split after the pre-cooler [12]. In addition, thermodynamic processes such as the reheating and the intermediate cooling can also be used to improve the efficiency of existing cycles further [10]. For these cycle layouts, a detailed description has been given in the literature [13].

Performance of different cycle layouts has been comprehensively compared by researchers. For instance, Turchi et al. [14] explored the thermodynamic performance of different $\mathrm{S}-\mathrm{CO}_{2}$ cycle layouts from the perspective of a concentrating solar power application. The results indicated that under dry cooling, cycle efficiency $50 \%$ could be obtained by partial-cooling S- $\mathrm{CO}_{2}$ Brayton cycle with reheating and intercooling $\mathrm{S}-\mathrm{CO}_{2}$ Brayton cycle with reheating. Zhu et al. [15] developed a mathematical model to conduct the thermodynamic analysis and comparison for different direct-heated $\mathrm{S}-\mathrm{CO}_{2}$ Brayton cycles integrated into a solar power tower system. It was found that the intercooling $\mathrm{S}-\mathrm{CO}_{2}$ cycle achieved the highest overall efficiency, followed by the recompression, the partial-cooling, the pre-compression, and the simple cycles at different turbine inlet temperatures. Thereafter, Wang et al. [9] simultaneously compared the efficiency and specific work for different $\mathrm{S}-\mathrm{CO}_{2}$ cycle layouts by obtaining the Pareto optimal fronts of multi-objective optimizations. The results suggested that the inter-cooling cycle layout and the partial-cooling cycle layout can generally yield the most excellent performances, followed by the recompression cycle layout and the precompression cycle layout. As for the application in nuclear energy, Moisseytsev and Sienicki [16] studied the performance of alternative $\mathrm{S}-\mathrm{CO}_{2}$ cycle layouts for a sodium-cooled fast reactor (SFR). It has been confirmed that slight gains in efficiency $(0.3 \%)$ of recompression cycle could be achieved by increasing the pressure to $22 \mathrm{MPa}$. Kulhanek and Dostal [17] compared thermal efficiency of precompression cycle, simple Brayton cycle and partial cooling cycle in nuclear reactors. It was found that the precompression cycle could achieve equivalent efficiency as the recompression cycle when turbine inlet temperature was above $700{ }^{\circ} \mathrm{C}$.

\subsection{Current Status of $\mathrm{CO}^{2}$-Based Mixtures}

Besides the structures of $\mathrm{S}-\mathrm{CO}_{2}$ power cycle, another way to improve the cycle performance is to use the $\mathrm{CO}_{2}$-based mixture as working fluid. This is because mixing with other gases can adjust the critical point of $\mathrm{CO}_{2}$, so as to change the lowest operation condition of the Brayton cycle. The direction and range of the critical point variation of $\mathrm{CO}_{2}$ depend on the mixed component and its amount. So far, a few studies have been conducted to discuss the feasibility and performance of the 
supercritical $\mathrm{CO}_{2}$-based mixture power cycle. For example, Sandia National Laboratories performed experimental tests on the compatibility of $\mathrm{CO}_{2}$ mixtures with the turbomachinery and the compressor operation in the supercritical region of mixtures [18]. Jeong et al. [19,20] developed a supercritical cycle model, based on the mixture properties. They investigated the performance of a supercritical $\mathrm{CO}_{2}$-based mixture cycle, which was applied to the power conversion of sodium cold fast reactor. It was found that the mixtures of $\mathrm{CO}_{2}-\mathrm{He}, \mathrm{CO}_{2}-\mathrm{Xe}$, and $\mathrm{CO}_{2}-\mathrm{Kr}$ had an increase in the total cycle efficiency, when the inlet temperature of main compressor is $1 \mathrm{~K}$ above the critical temperature of mixtures. Thereafter, Hu et al. [21] analyzed the performance of a nuclear reactor integrated with the $\mathrm{CO}_{2}$-based mixture cycle. The obtained results indicated that the adoption of $\mathrm{CO}_{2}-\mathrm{He}$ and $\mathrm{CO}_{2}-\mathrm{Kr}$ could increase the cycle efficiency and decrease the amounts of heat transfer in the HTR and LTR. In order to reduce the air-cooled waste heat removal difficulty, Baik and Lee [22] compared the simple cycle performance of $\mathrm{CO}_{2}-\mathrm{SF}_{6}, \mathrm{CO}_{2}-\mathrm{R} 123, \mathrm{CO}_{2}-\mathrm{R} 134 \mathrm{a}, \mathrm{CO}_{2}-\mathrm{R} 32$, and $\mathrm{CO}_{2}$ - toluene under the minimum temperature $304.15-313.15 \mathrm{~K}$ and the maximum temperature $573.15 \mathrm{~K}$. It was concluded that $\mathrm{CO}_{2}-\mathrm{R} 32$ and $\mathrm{CO}_{2}$-Toluene could potentially reduce the efficiency degradation of pure $\mathrm{S}-\mathrm{CO}_{2}$ power cycles at higher heat sink temperatures. Recently, Guo et al. [23] also analyzed the thermodynamic performance of four different Brayton cycles using $\mathrm{CO}_{2}$ mixtures in the molten salt solar power tower systems. The used mixtures were $\mathrm{CO}_{2}$-Xe (0.7/0.3) and $\mathrm{CO}_{2}$-butane (0.95/0.05). The results indicated that adding xenon into $\mathrm{S}-\mathrm{CO}_{2}$ cycle could obviously improve the overall thermal efficiency and exergy efficiency, while the effects of butane as an additive were converse. On the other hand, in engineering application of Brayton cycle, $\mathrm{S}-\mathrm{CO}_{2}$ will be inevitably mixed with the gas impurities. Therefore, Vesely et al. [24] investigated the effect of gaseous admixtures on the cycle efficiency at a fixed inlet temperature of main compressor. They found that all researched mixtures except $\mathrm{CO}_{2}-\mathrm{H}_{2} \mathrm{~S}$ had negative effects on the cycle efficiency and net power output. Thereafter, they examined the effect of different impurity compositions on the performance of various cycle components at different inlet temperatures of main compressor [25]. The above studies on the Brayton cycle with $\mathrm{CO}_{2}$-based mixtures are summarized in Table 1.

Table 1. Research summary on the Brayton cycle with $\mathrm{CO}_{2}$-based mixtures.

\begin{tabular}{|c|c|c|c|c|c|}
\hline Authors & Year & Mixtures & $T_{c} /$ Mole Fraction & Inlet Temperature of Compressor & Performance Parameters \\
\hline Jeong et al. [20] & 2011 & $\begin{array}{l}\mathrm{CO}_{2}-\mathrm{N}_{2} \mathrm{CO}_{2}-\mathrm{O}_{2} \\
\mathrm{CO}_{2}-\mathrm{He} \mathrm{CO}_{2}-\mathrm{Ar}\end{array}$ & $292 \mathrm{~K}-304 \mathrm{~K}$ & $T_{c}+1$ & cycle efficiency \\
\hline Conboy et al. [18] & 2012 & $\begin{array}{c}\mathrm{CO}_{2}-\mathrm{He} \mathrm{CO}_{2}-\mathrm{Ne} \\
\mathrm{CO}_{2} \text {-methane } \\
\mathrm{CO}_{2} \text {-butane } \\
\mathrm{CO}_{2} \text {-Xe CO} \mathrm{CO}_{2}-\mathrm{Kr}\end{array}$ & $\begin{array}{c}0.9 / 0.1 \\
0.81 / 0.19 ; 0.92 / 0.08\end{array}$ & - & $\begin{array}{l}\text { Compatibility; } \\
\text { compressor flow }\end{array}$ \\
\hline Jeong et al. [19] & 2013 & $\begin{array}{c}\mathrm{CO}_{2}-\mathrm{N}_{2} \mathrm{CO}_{2}-\mathrm{O}_{2} \\
\mathrm{CO}_{2}-\mathrm{Ar}\end{array}$ & $292 \mathrm{~K}-304 \mathrm{~K}$ & $T_{c}+1$ & cycle efficiency \\
\hline Hu et al. [21] & 2015 & $\begin{array}{c}\mathrm{CO}_{2}-\mathrm{O}_{2} \mathrm{CO}_{2}-\mathrm{He} \\
\mathrm{CO}_{2}-\mathrm{Ar} \mathrm{CO} \mathrm{CO}_{2}-\mathrm{Kr} \\
\mathrm{CO}_{2} \text {-butane } \\
\mathrm{CO}_{2} \text {-cyclohexane }\end{array}$ & $\begin{array}{l}284.15 \mathrm{~K}-304.15 \mathrm{~K} \\
304.15 \mathrm{~K}-324.15 \mathrm{~K}\end{array}$ & $T_{c}+1$ & $\begin{array}{l}\text { heat transfer; } \\
\text { mass flow rate; } \\
\text { cycle power; } \\
\text { cycle efficiency }\end{array}$ \\
\hline Vesely et al. [24] & 2016 & $\begin{array}{c}\mathrm{CO}_{2}-\mathrm{He}_{\mathrm{CO}}-\mathrm{H}_{2} \\
\mathrm{CO}_{2}-\mathrm{O}_{2} \mathrm{CO}_{2}-\mathrm{H}_{2} \mathrm{~S} \\
\mathrm{CO}_{2}-\mathrm{N}_{2} \mathrm{CO}_{2}-\mathrm{Ar} \\
\mathrm{CO}_{2}-\mathrm{SF}_{6} \\
\mathrm{CO}_{2}-\mathrm{R} 123\end{array}$ & impurity: $0-0.05$ & $307.15 \mathrm{~K}$ & cycle efficiency \\
\hline Baik and Lee [22] & 2018 & $\begin{array}{c}\mathrm{CO}_{2}-\mathrm{R} 134 \mathrm{a} \\
\mathrm{CO}_{2}-\mathrm{R} 32 \\
\mathrm{CO}_{2} \text {-toluene }\end{array}$ & $\mathrm{CO}_{2}: 0-1$ & $304.15 \mathrm{~K}-313.15 \mathrm{~K}$ & cycle efficiency \\
\hline Ma et al. [26] & 2018 & $\mathrm{CO}_{2}-\mathrm{Kr}$ & Kr: $0-0.48$ & - & $\begin{array}{c}\text { cycle efficiency; cooling } \\
\text { capacity }\end{array}$ \\
\hline Vesely et al. [25] & 2019 & $\begin{array}{l}\mathrm{CO}_{2}-\mathrm{He} \mathrm{CO}_{2}-\mathrm{CO} \\
\mathrm{CO}_{2}-\mathrm{O}_{2} \mathrm{CO}_{2}-\mathrm{N}_{2} \\
\mathrm{CO}_{2}-\mathrm{Ar} \mathrm{CO}_{2}-\mathrm{Xe}\end{array}$ & impurity: $0-0.10$ & $307.15 \mathrm{~K}-313.15 \mathrm{~K}$ & $\begin{array}{l}\text { cycle power; } \\
\text { heat transfer }\end{array}$ \\
\hline Guo et al. [23] & 2019 & $\begin{array}{c}\mathrm{CO}_{2} \text {-butane } \\
\mathrm{CO}_{2} \text {-Xe }\end{array}$ & $\begin{array}{c}0.95 / 0.05 \\
0.7 / 0.3\end{array}$ & $\begin{array}{l}313.15 \mathrm{~K}-333.15 \mathrm{~K} \\
303.15 \mathrm{~K}-333.15 \mathrm{~K} \\
\end{array}$ & $\begin{array}{l}\text { cycle efficiency; exery } \\
\text { efficiency }\end{array}$ \\
\hline
\end{tabular}

From Table 1, it can be observed that the existing studies have the following limits:

(1) For the studies of Jeong et al. [19,20] and Hu et al. [21], the inlet temperature of main compressor is always assumed to be $1 \mathrm{~K}$ above the critical temperature of corresponding mixture, namely 
$T_{\mathcal{C}}+1$. However, due to the fact that $T_{\mathcal{C}}$ is different for various mixtures, this assumption will cause the performance comparison of mixtures under different compressor inlet temperatures.

(2) For the work of Vesely et al. [24,25] and Guo et al. [23], the range of employed gas fraction is too less. Although Baik and Lee [22] considered the whole fraction range 0-1, most of the employed additives belong to organic fluids, which may decompose in the high temperature. Furthermore, Baik and Lee [22] only analyzed the performance of simple Brayton cycle.

(3) Cycle efficiency is mainly employed to evaluate the cycle performance of different $\mathrm{CO}_{2}$-based mixtures. Thus, more detailed performance comparisons are required.

\subsection{Contribution of the Study}

Considering the limits of the existing studies on the $\mathrm{CO}_{2}$-based mixtures, this work will comprehensively conduct the investigation of recompression cycle performance and the recuperator analysis under the same inlet temperature of main compressor. The studied range of $\mathrm{CO}_{2}$ mass fraction is $0-1$. Parameters such as cycle efficiency, specific work, mass flow rate, heat input and heat conductance, are compared for different $\mathrm{CO}_{2}$-based mixtures. Furthermore, considering that the inlet temperature of main compressor is closely related with ambient temperature, this work will also reveal the effect of compressor inlet temperature on the performance of $\mathrm{CO}_{2}$-based mixtures and recuperators in the recompression cycle.

\section{Cycle Layout and $\mathrm{CO}_{2}$-Based Mixtures}

\subsection{Cycle Layout}

For different configurations of the $\mathrm{S}-\mathrm{CO}_{2}$ power cycle, the recompression cycle is the most representative, because of its relative simplicity and higher efficiency $[20,23]$. Furthermore, introducing a reheating process into the cycle can further improve the performance. Thus, in this work, the recompression cycle with reheater is employed to analyze and compare the performances of different $\mathrm{CO}_{2}$-based mixtures. As shown in Figure 1, the considered cycle consists of a primary heater, reheater, HPT (high pressure turbine), LPT (low pressure turbine), HTR, LTR, compressor, recompressor and gas cooler. The working fluid firstly receives the thermal energy in the primary heater. After generating work in the HPT, the working fluid is reheated at the medium pressure and then produces work in the LPT. Thereafter, the low-pressure fluid flows through the HTR and LTR in turn. Before entering the gas cooler, the flow is split into two streams. One stream flows through the cooler and then is compressed to a high pressure in the main compressor, while the other stream flows through the recompressor. The high-pressure stream from the main compressor flows into the LTR and absorbs heat from the low pressure working fluid. Then, the preheated stream merges with the working fluid from the recompressor. After that, the combined flow is further preheated by the low-pressure working fluid in the HTR, and finally returns to the primary heater.

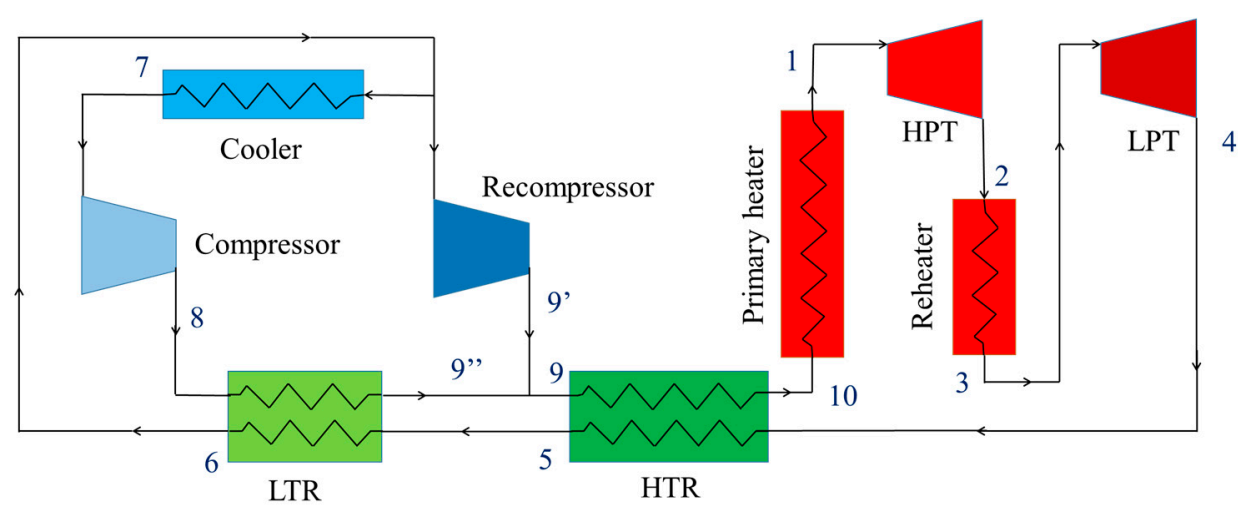

Figure 1. Schematic of recompression cycle with reheater. 
For the above recompression cycle with a reheater, when employing $\mathrm{CO}_{2}$ as working fluid, the corresponding T-s (Temperature-entropy) diagram is presented in Figure 2. As the lowest cycle operation parameters, the inlet temperature and pressure of main compressor should be located just above the critical point of $\mathrm{CO}_{2}$ to reduce the required compressor work. Furthermore, when two divided streams merge at the inlet of HTR, the corresponding temperature difference should be small enough to avoid thermal fatigue cracking of the channel wall. Thus, a suitable flow split ratio must be determined for the recompression cycle.

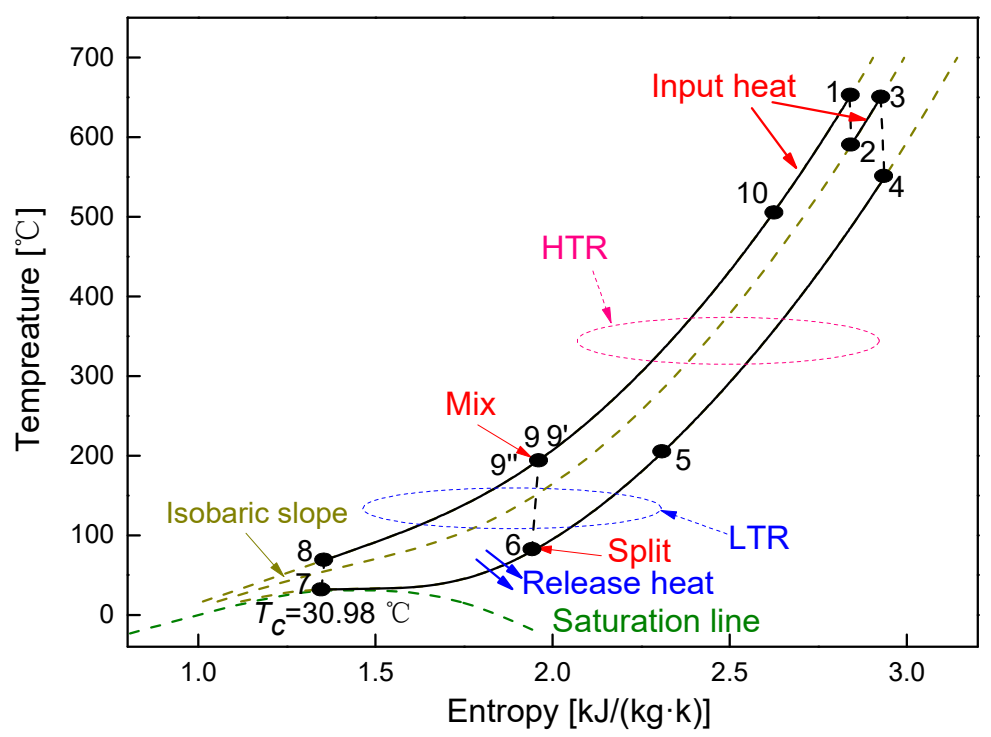

Figure 2. Temperature-entropy diagram of $\mathrm{S}-\mathrm{CO}_{2}$ recompression cycle with reheater.

\section{2. $\mathrm{CO}_{2}$-Based Mixtures}

Table 1 lists the considered $\mathrm{CO}_{2}$-based mixtures in the existing studies. Thermodynamic properties of these mixtures are always obtained by REFPROP [19-26]. According to the shift direction of critical temperature, these mixtures can be classified into two groups: the ascending critical temperature group and the descending critical temperature group. In general, the ascending critical temperature group contains organic fluids such as butane, R134a, and R123. These constituents may decompose at high temperatures. However, for the descending critical temperature group, the additives usually include $\mathrm{O}_{2}, \mathrm{~N}_{2}$, and Ar, which have the characteristics of safety, thermostability, and compatibility. Under the high temperature and pressure conditions, these gases would not be reacted with $\mathrm{CO}_{2}$. Furthermore, in engineering applications of the $\mathrm{S}-\mathrm{CO}_{2}$ cycle, the gases usually appear as the impurities. Therefore, in this work, seven additive gases are employed, as presented in Table 2.

Table 2. Pure fluids involved in the considered $\mathrm{CO}_{2}$-based mixtures.

\begin{tabular}{cccccccc}
\hline \multirow{2}{*}{ Pure Fluid } & $\boldsymbol{M}[\mathrm{g} / \mathbf{m o l}]$ & $\boldsymbol{T}_{\boldsymbol{b}}[\mathrm{K}]$ & $\boldsymbol{T}_{\boldsymbol{c}}[\mathrm{K}]$ & $\boldsymbol{P}_{\boldsymbol{c}}[\mathrm{MPa}]$ & $\boldsymbol{D}_{\boldsymbol{c}}\left[\mathbf{k g} / \mathbf{m}^{\mathbf{3}}\right]$ & \multicolumn{2}{c}{$\left.\boldsymbol{C}_{\boldsymbol{p}}[\mathrm{KJ} / \mathbf{( k g} \cdot \mathbf{K})\right]$} \\
\hline $\mathrm{CO}_{2}$ & 44.01 & 194.69 & 304.13 & 7.38 & 467.60 & 1.14 & 1.55 \\
$\mathrm{Xe}$ & 131.29 & 165.05 & 289.73 & 5.84 & 1102.90 & 0.21 & 0.32 \\
$\mathrm{Kr}$ & 83.80 & 119.73 & 209.48 & 5.53 & 909.21 & 0.28 & 0.34 \\
$\mathrm{O}_{2}$ & 32.00 & 90.19 & 154.58 & 5.04 & 436.14 & 1.00 & 0.08 \\
$\mathrm{Ar}$ & 39.95 & 87.30 & 150.69 & 4.86 & 535.60 & 0.55 & 1.16 \\
$\mathrm{~N}_{2}$ & 28.01 & 77.36 & 126.19 & 3.40 & 313.30 & 1.09 & 1.05 \\
$\mathrm{Ne}$ & 20.18 & 27.10 & 44.49 & 2.68 & 481.91 & 1.04 & 5.18 \\
$\mathrm{He}$ & 4.00 & 4.22 & 5.20 & 0.23 & 69.58 & 5.19 & $\boldsymbol{T}_{\boldsymbol{c} \mathbf{0}}+\mathbf{1 5 0}, \mathbf{2 5} \mathbf{M p a}$ \\
\hline
\end{tabular}

Table 2 lists the pure gases involved in the considered $\mathrm{CO}_{2}$-based mixtures, according to the decrease sequence of critical temperature: $\mathrm{CO}_{2}>\mathrm{Xe}>\mathrm{Kr}>\mathrm{O}_{2}>\mathrm{Ar}>\mathrm{N}_{2}>\mathrm{Ne}>\mathrm{He}$. For every gas, 
Table 2 provides molecular weight, boiling temperature and critical properties. Furthermore, under the temperature $T_{c 0}+150 \mathrm{~K}(454.13 \mathrm{~K})$, heat capacities at pressures $7.5 \mathrm{MPa}$ and $25 \mathrm{MPa}$ are given, based on the calculation of REFPROP. From the table, it can be seen that $\mathrm{CO}_{2}$ has the highest critical temperature $304.13 \mathrm{~K}$, while He has the lowest critical temperature $5.1953 \mathrm{~K}$. For the seven additive gases, Xe has closest critical temperature $(289.73 \mathrm{~K})$ to that of $\mathrm{CO}_{2}$. Furthermore, the boiling temperature and the critical pressure decrease with the decrease of critical temperature. For the critical density, Xe has the highest value $\left(1102.9 \mathrm{~kg} / \mathrm{m}^{3}\right)$, while He has the lowest density $\left(69.58 \mathrm{~kg} / \mathrm{m}^{3}\right)$. As for the heat capacity, He has much higher value than other fluids under the same condition. In addition, the heat capacity at high pressure is always larger than that at low pressure. However, for different fluids, with the decrease of critical temperature, the difference of heat capacity between different pressures decreases. Although this heat capacity difference is small, if the difference is multiplied by the mass flow rate, the difference of total heat capacity will be considerable to affect the heat exchange in the recuperator. That is why the split flow process is widely employed in the configurations of the $\mathrm{S}-\mathrm{CO}_{2}$ power cycle. The mismatch of heat capacity in the LTR can be greatly alleviated by adjusting the mass flow rate at the high-pressure side of heat exchanger.

For the considered $\mathrm{CO}_{2}$-based mixtures, the corresponding thermodynamic properties are evaluated by the newest version REFPROP 10 [27]. The variations of critical temperature and pressure with the mass fraction of $\mathrm{CO}_{2}$ are respectively presented in Figures 3 and 4 . Figure 3 indicates that the critical temperature of mixture increases monotonously with the increase of $\mathrm{CO}_{2}$ mass fraction. The curves of these mixtures are distributed according to the order of critical temperature of pure gases. However, it should be noted that although critical temperature satisfies $\mathrm{O}_{2}>\mathrm{Ar}, \mathrm{CO}_{2}-\mathrm{Ar}$ has an obviously higher critical temperature than that of $\mathrm{CO}_{2}-\mathrm{O}_{2}$ at mass fractions larger than 0.2. Critical temperature of mixtures usually satisfies the following order: $\mathrm{CO}_{2}-\mathrm{Xe}>\mathrm{CO}_{2}-\mathrm{Kr}>\mathrm{CO}_{2}-\mathrm{Ar}>\mathrm{CO}_{2}-\mathrm{O}_{2}>$ $\mathrm{CO}_{2}-\mathrm{N}_{2}>\mathrm{CO}_{2}-\mathrm{Ne}>\mathrm{CO}_{2}$-He. Furthermore, when $\mathrm{CO}_{2}$ mass fraction is larger than 0.5 , the curves of $\mathrm{CO}_{2}-\mathrm{O}_{2}$ and $\mathrm{CO}_{2}-\mathrm{N}_{2}$ are close to each other. As for the critical pressure of mixture in Figure 4, there exist very different variation trends among the mixtures. From Figure 4 , it can be seen that with the increase of $\mathrm{CO}_{2}$ mass fraction, critical pressures of mixtures $\mathrm{CO}_{2}-\mathrm{Ar}, \mathrm{CO}_{2}-\mathrm{N}_{2}$, and $\mathrm{CO}_{2}-\mathrm{O}_{2}$ first increase and then decrease. It means that there exists a high peak value of critical pressure, especially for $\mathrm{CO}_{2}$-Ar. For the mixtures $\mathrm{CO}_{2}-\mathrm{Xe}, \mathrm{CO}_{2}-\mathrm{Kr}$, and $\mathrm{CO}_{2}-\mathrm{Ne}$, as the mass fraction of $\mathrm{CO}_{2}$ increases, the critical pressure shows slowly increase monotonously. As for $\mathrm{CO}_{2}-\mathrm{He}$, it should be noted that when $\mathrm{CO}_{2}$ mass fraction approaches to 1.0, the critical pressure of $\mathrm{CO}_{2}-\mathrm{He}$ is a little higher than that of $\mathrm{CO}_{2}$ in a small range of mass fraction.

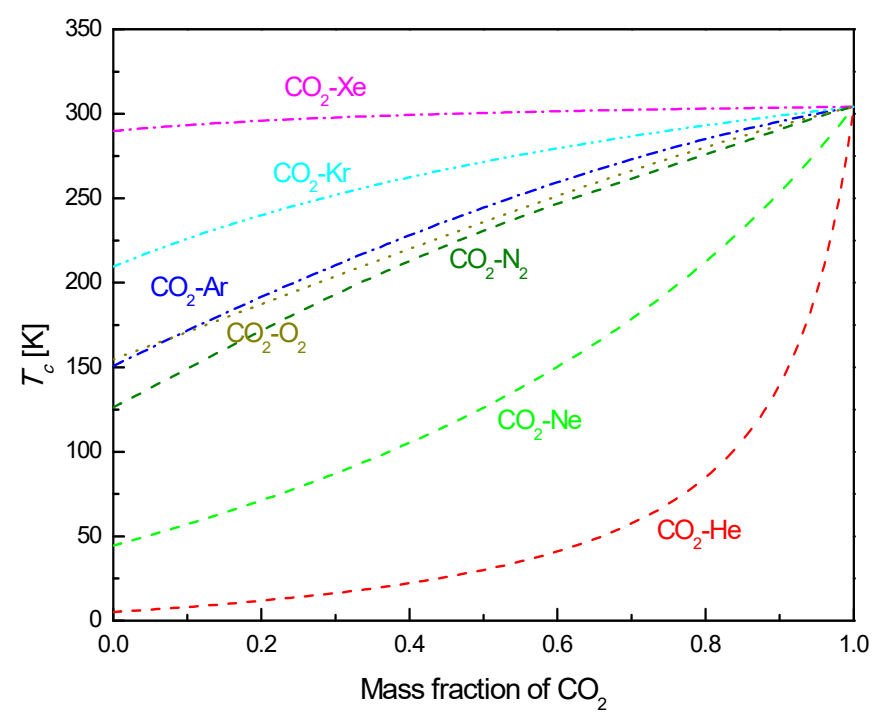

Figure 3. Critical temperature of mixtures at different mass fractions of $\mathrm{CO}_{2}$. 


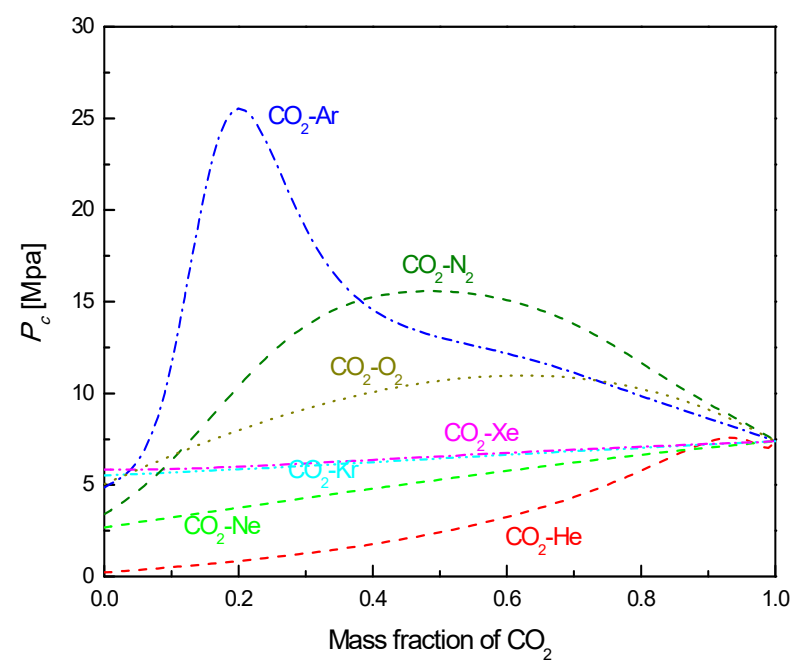

Figure 4. Critical pressure of mixtures at different mass fractions of $\mathrm{CO}_{2}$.

\section{Thermodynamic Model and Validation}

\subsection{Model Establishment}

In order to analyze the cycle performance of $\mathrm{CO}_{2}$-based mixtures, a simulation model is developed for the recompression cycle with reference to Figures 1 and 2. For the simplicity of modeling, the following assumptions are applied in the establishment of simulation model.

- The recompression cycle is reached in steady state operating condition.

- $\quad$ Pressure drops and heat losses in the pipes and heat exchangers are ignored.

- $\quad$ Recuperators are considered as counter-flow heat exchangers.

The power generated by the HPT and LPT can be determined as follows:

$$
\begin{gathered}
W_{\mathrm{HPT}}=m_{c}\left(h_{1}-h_{2}\right)=m_{c}\left(h_{1}-h_{2 s}\right) \eta_{\mathrm{HPT}} \\
W_{\mathrm{LPT}}=m_{c}\left(h_{3}-h_{4}\right)=m_{c}\left(h_{3}-h_{4 s}\right) \eta_{\mathrm{LPT}}
\end{gathered}
$$

For the consumed work in the main compressor and recompressor, it can be expressed from Equations (3) and (4).

$$
\begin{gathered}
W_{M C}=S R \times m_{c} \times\left(h_{8}-h_{7}\right)=S R \times m_{c} \times\left(h_{8 s}-h_{7}\right) / \eta_{M C} \\
W_{R C}=(1-S R) \times m_{c} \times\left(h_{9^{\prime}}-h_{7}\right)=(1-S R) \times m_{c} \times\left(h_{9^{\prime} s}-h_{7}\right) / \eta_{R C}
\end{gathered}
$$

where split ratio (SR) denotes the ratio of the main compressor mass flow to the cycle mass flow and is defined as

$$
S R=m_{M C} / m_{C}
$$

Thus, the net power output is

$$
W_{\text {net }}=W_{\mathrm{HPT}}+W_{\mathrm{LPT}}-W_{M C}-W_{R C}
$$

The input heat through the primary heater and reheater is expressed as

$$
\begin{gathered}
Q_{p h}=m_{c}\left(h_{1}-h_{10}\right) \\
Q_{r h}=m_{c}\left(h_{3}-h_{2}\right)
\end{gathered}
$$


For the primary heater, the temperature increase of working fluid is defined as

$$
\Delta t=T_{1}-T_{10}
$$

Furthermore, for the reheater, according to the reference [28], the intermediate pressure of working fluid is set as the average of the high and low pressures.

Based on the above parameters, the thermal efficiency can be described using Equation (10)

$$
\eta_{c}=W_{n e t} /\left(Q_{p h}+Q_{r h}\right)
$$

As for the heat exchange in the LTR and HTR, energy balance is satisfied.

$$
\begin{gathered}
h_{4}-h_{5}=h_{10}-h_{9} \\
h_{5}-h_{6}=S R \times\left(h_{9^{\prime \prime}}-h_{8}\right)
\end{gathered}
$$

In the modeling of recuperators, the effectiveness approach is employed. For LTR and HTR, the effectiveness is respectively defined as [5]

$$
\begin{aligned}
& \varepsilon_{L T R}=\left(h_{5}-h_{6}\right) /\left(h_{5}-h\left(T_{8}, P_{L}\right)\right) \\
& \varepsilon_{H T R}=\left(h_{4}-h_{5}\right) /\left(h_{4}-h\left(T_{9}, P_{L}\right)\right)
\end{aligned}
$$

Furthermore, for the mixing process of two divided flows, it is governed by

$$
S R \times h_{9^{\prime}}+(1-S R) \times h_{9^{\prime \prime}}=h_{9}
$$

For the recuperators, since heat transfer coefficients of mixtures are different with each other, heat conduction (UA), as a product of heat transfer coefficient and area, is employed to represent the required size and transfer performance of the heat exchangers. In general, a larger UA results into a higher cost of heat exchanger. UA can be calculated by knowing the inlet and outlet temperatures of recuperator. Considering that the thermodynamic properties of $\mathrm{CO}_{2}$-based mixture vary greatly with the temperature, the recuperator is discretized into N sub-heat exchangers. Due to the slight variation of properties, they can be assumed as constants in each sub-heat exchanger. Accordingly, the total heat transfer rate of recuperator is divided into $\mathrm{N}$ sections. For each sub-heat exchanger, the transferred heat is expressed by

$$
Q_{j}=m_{\text {hot }}\left(h_{h o t, i n, j}-h_{\text {hot }, o u t, j}\right)=m_{\text {cold }}\left(h_{\text {cold }, o u t, j}-h_{\text {cold }, i n, j}\right)
$$

The corresponding logarithmic mean temperature difference is expressed as

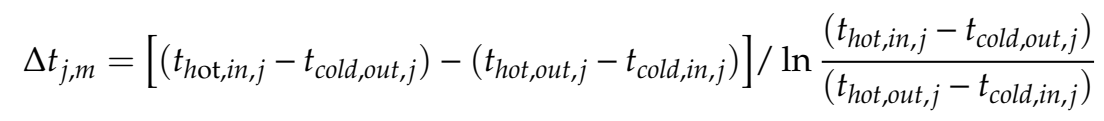

Then, the heat conductance of sub-heat exchanger can be obtained, and the overall conductance is calculated as

$$
\mathrm{UA}=\sum_{j=1}^{N} Q_{j} / \Delta t_{j, m}
$$

In order to compare the cycle performance of different mixtures, main parameters of the recompression cycle are specified in Table 3. These parameters are designed by National Renewable Energy Laboratory for the application of $\mathrm{S}^{-\mathrm{CO}_{2}}$ Brayton cycle in concentrating solar power. The corresponding reference values have been employed in the performance comparison among the simple cycle, recompression cycle and partial-cooling cycle [28]. In the table, the efficiencies of 
turbomachinery are provided, and the effectiveness of heat exchanger is given. In order to guarantee the heat transfer in HTR and LTR, the temperature difference in heat exchanger is set to be above $5{ }^{\circ} \mathrm{C}$. In addition, the highest cycle temperature and maximum pressure are set to be $650^{\circ} \mathrm{C}$ and $25 \mathrm{MPa}$, respectively. As for the lowest cycle temperature, the reference value of compressor inlet temperature is set to be just $1 \mathrm{~K}$ above the critical temperature of $\mathrm{CO}_{2}\left(T_{c 0}+1\right)$. However, in order to investigate the effect of compressor inlet temperature on the cycle performance, the inlet temperature also varies from $T_{c 0}+1$ to $T_{c 0}+30$. Furthermore, it is assumed that the recompression system has a net power output of $35 \mathrm{MW}$.

Table 3. Main parameters for the recompression power cycle with reheater.

\begin{tabular}{ccc}
\hline Design Parameters & Value Range & Reference Value \\
\hline Turbine efficiency & 0.93 & 0.93 \\
Compressor efficiency & 0.89 & 0.89 \\
Heat exchanger effectiveness & 0.97 & 0.97 \\
Temperature difference in heat & $\geq 5{ }^{\circ} \mathrm{C}$ & $\geq 5^{\circ} \mathrm{C}$ \\
exchanger & $650^{\circ} \mathrm{C}$ & $650^{\circ} \mathrm{C}$ \\
Turbine inlet temperature & $T_{c 0}+1-T_{c 0}+30$ & $T_{c 0}+1$ \\
Compressor inlet temperature & $25 \mathrm{MPa}$ & $25 \mathrm{MPa}$ \\
Upper pressure & $35 \mathrm{MW}$ & $35 \mathrm{MW}$ \\
Net power output & &
\end{tabular}

Under the design parameters in Table 3, pressure ratio and split ratio are optimized for each fluid based on the criteria of maximum cycle efficiency. The optimization procedure is shown in Figure 5 . For the calculation of LTR and HTR, the temperature distributions are obtained, and the minimum temperature differences are checked at the pinch point. If the pinch point temperature difference (PPTD) is lower than $5{ }^{\circ} \mathrm{C}$, parameters of LTR and HTR are recalculated by setting PPTD $=5{ }^{\circ} \mathrm{C}$. Computer programs for this calculation procedure are developed on the platform of MATLAB 2015. REFPROP 10 is embedded into the program to determine the thermodynamic properties of $\mathrm{CO}_{2}$-based mixtures at different state points.

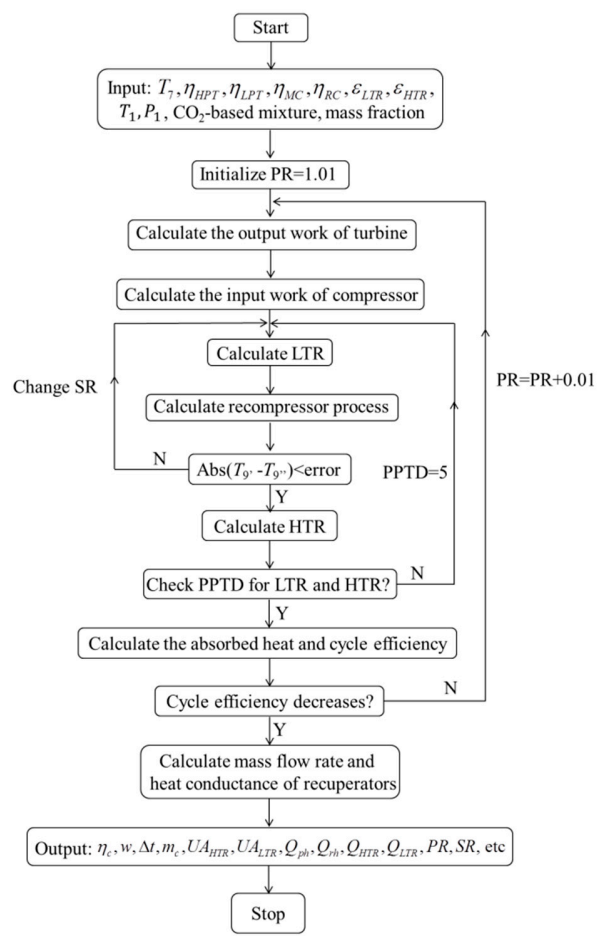

Figure 5. Calculation flow chart of the cycle with $\mathrm{CO}_{2}$-based mixtures. 


\subsection{Model Validation}

The established model is validated by comparing the results with the data of Neises and Turchi's study [28]. In the validation, the working fluid is supercritical $\mathrm{CO}_{2}$ and the adopted parameters are consistent with the reference values in Table 3, except that the compressor inlet temperature is assumed to be $50{ }^{\circ} \mathrm{C}$. Based on the above parameters, Neises and Turchi got results using Engineering Equation Solver (University of Wisconsin-Madison, Madison, WI, US), while results of the present model are obtained by running MATLAB. Table 4 gives the comparison results of these two models. It can be seen that there exists a good agreement between the present model and the reference.

Table 4. Comparison results between the present study and reference [28].

\begin{tabular}{ccc}
\hline Cycle Parameters & REF [28] & Present Study \\
\hline Pressure ratio & 2.50 & 2.50 \\
Split ratio & 0.71 & 0.71 \\
UA $_{\text {LTR }}[\mathrm{MW} / \mathrm{K}]$ & 3.21 & 3.21 \\
$\mathrm{UA}_{\text {HTR }}[\mathrm{MW} / \mathrm{K}]$ & 5.33 & 5.31 \\
UA $_{\text {total }}[\mathrm{MW} / \mathrm{K}]$ & 8.54 & 8.52 \\
Cycle efficiency & 0.49 & 0.49 \\
\hline
\end{tabular}

\section{Results and Discussions}

Under the design conditions in Table 3, optimized results of recompression cycle are obtained for $\mathrm{CO}_{2}$-based mixtures. The employed $\mathrm{CO}_{2}$ mass fraction varies from 0 to 1 at an interval of 0.1 . The corresponding calculated data are listed in Supplementary Materials. On this basis, thermodynamic analysis on cycle performance and recuperator is conducted for mixtures under a fixed compressor inlet temperature $\left(T_{c 0}+1\right)$. Thereafter, cycle parameters are optimized at different compressor inlet temperatures, so that the effect can be revealed for mixtures.

\subsection{Cycle Performance Analysis}

Figure 6 presents the calculated cycle efficiency of mixtures at different mass fractions of $\mathrm{CO}_{2}$. It can be seen that every mixture has a unique variation curve of cycle efficiency with the increase of $\mathrm{CO}_{2}$ mass fraction. For $\mathrm{CO}_{2}-\mathrm{Xe}$, as the $\mathrm{CO}_{2}$ mass fraction increases from 0 to 1 , the cycle efficiency firstly increases from the value of $\mathrm{Xe}(0.538)$ and then decreases slowly to the value of $\mathrm{CO}_{2}(0.539)$. It means that there exists a peak value of cycle efficiency around the $\mathrm{CO}_{2}$ mass fraction 0.2 . Due to the little difference of critical temperatures between $\mathrm{CO}_{2}$ and $\mathrm{Xe}$, the range of efficiency variation is small for $\mathrm{CO}_{2}$-Xe. Unlike the mixture $\mathrm{CO}_{2}$-Xe, the efficiency of the rest mixtures always increases with the increase of $\mathrm{CO}_{2}$ mass fraction. Since the critical temperature of $\mathrm{CO}_{2}$ is much higher than temperatures of pure gases, cycle efficiencies of these gases are far lower than that of $\mathrm{CO}_{2}$ under the fixed compressor inlet temperature. Furthermore, for mixtures $\mathrm{CO}_{2}-\mathrm{O}_{2}, \mathrm{CO}_{2}-\mathrm{Ar}, \mathrm{CO}_{2}-\mathrm{N}_{2}, \mathrm{CO}_{2}-\mathrm{Ne}$, and $\mathrm{CO}_{2}-\mathrm{He}$, the cycle efficiency increases slowly at the fraction range 0-0.9. However, when $\mathrm{CO}_{2}$ mass fraction approaches to 1.0, a sharp increase of efficiency is observed. On the other hand, for the considered mixtures, the legend is illustrated according to the descending order of the critical temperatures of pure gases. Figure 6 indicates that with the critical temperature decrease of pure gases, the corresponding mixtures usually have lower cycle efficiency. However, for the gases $\mathrm{O}_{2}$ and $\mathrm{Ar}$, efficiency of $\mathrm{CO}_{2}$-Ar is always higher than that of $\mathrm{CO}_{2}-\mathrm{O}_{2}$. This is because, although the critical temperature of $\mathrm{O}_{2}$ is higher than that of $\mathrm{Ar}$, the critical temperature of $\mathrm{CO}_{2}-\mathrm{O}_{2}$ is lower than that of $\mathrm{CO}_{2}$-Ar. Thus, the considered mixtures satisfy the following order of cycle efficiency: $\mathrm{CO}_{2}-\mathrm{Xe}>\mathrm{CO}_{2}-\mathrm{Kr}>\mathrm{CO}_{2}-\mathrm{Ar}>\mathrm{CO}_{2}-\mathrm{O}_{2}>\mathrm{CO}_{2}-\mathrm{N}_{2}>$ $\mathrm{CO}_{2}-\mathrm{Ne}>\mathrm{CO}_{2}-\mathrm{He}$. In addition, when the critical temperature of mixture is far from the compressor inlet temperature, the efficiency difference of different mixtures such as $\mathrm{CO}_{2}-\mathrm{N}_{2}, \mathrm{CO}_{2}-\mathrm{Ne}$, or $\mathrm{CO}_{2}-\mathrm{He}$ becomes smaller. 


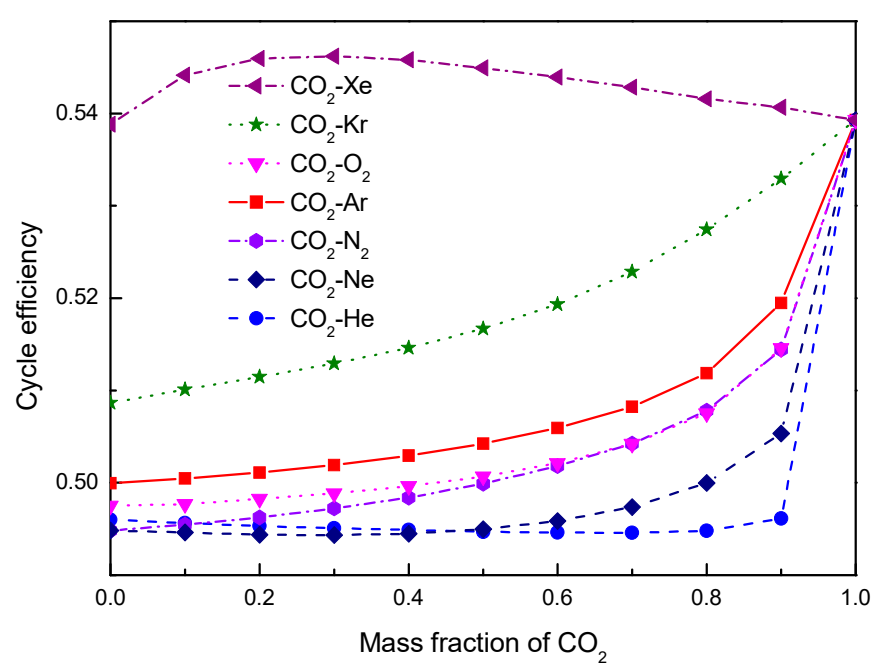

Figure 6. Cycle efficiency of mixtures at different mass fractions of $\mathrm{CO}_{2}$.

For the mixtures, Figure 7 presents the variation of specific work (output work per mass flow rate) with the mass fraction of $\mathrm{CO}_{2}$. It can be seen that specific work of $\mathrm{He}(396.14 \mathrm{~kW})$ is much higher than that of $\mathrm{CO}_{2}(139.61 \mathrm{~kW})$. Thus, the mixture $\mathrm{CO}_{2}-\mathrm{He}$ shows a continue decrease of specific work in the $\mathrm{CO}_{2}$ mass fraction range 0-0.9. When the mass fraction approaches to 1.0, the output work will increase to that of pure $\mathrm{CO}_{2}$. For the other mixtures, as $\mathrm{CO}_{2}$ mass fraction increases, the corresponding output work slowly increases from the value of pure gas to that of $\mathrm{CO}_{2}$. However, the variation range is smaller than that of $\mathrm{CO}_{2}-\mathrm{He}$. It is interesting to note that $\mathrm{CO}_{2}-\mathrm{He}$ has the lowest efficiency, while the output work of $\mathrm{CO}_{2}-\mathrm{He}$ is the highest in the $\mathrm{CO}_{2}$ mass fraction rang 0-0.8. Furthermore, due to the fact that the net power output is given in the simulation, mass flow rates of mixtures can be determined, as shown in Figure 8. Mass flow rates of $\mathrm{Kr}, \mathrm{Xe}$, and Ar reach to $1225.14 \mathrm{~kg} / \mathrm{s}, 982.78 \mathrm{~kg} / \mathrm{s}$, and $744.22 \mathrm{~kg} / \mathrm{s}$, respectively. With the increase of $\mathrm{CO}_{2}$ mass fraction, the flow rates gradually decrease to the value of $\mathrm{CO}_{2}(250.69 \mathrm{~kg} / \mathrm{s})$. Although mass flow rates of $\mathrm{CO}_{2}-\mathrm{Ne}, \mathrm{CO}_{2}-\mathrm{O}_{2}$, and $\mathrm{CO}_{2}-\mathrm{N}_{2}$ satisfies the order $\mathrm{CO}_{2}-\mathrm{Ne}>\mathrm{CO}_{2}-\mathrm{O}_{2}>\mathrm{CO}_{2}-\mathrm{N}_{2}$, the curves of these mixtures are close to each other. The lowest curve of mass flow rate is observed for $\mathrm{CO}_{2}$ - He. As $\mathrm{CO}_{2}$ mass fraction increases, mass flow rate of $\mathrm{He}$ $(88.35 \mathrm{~kg} / \mathrm{s})$ starts to increase to that of $\mathrm{CO}_{2}(250.69 \mathrm{~kg} / \mathrm{s})$.

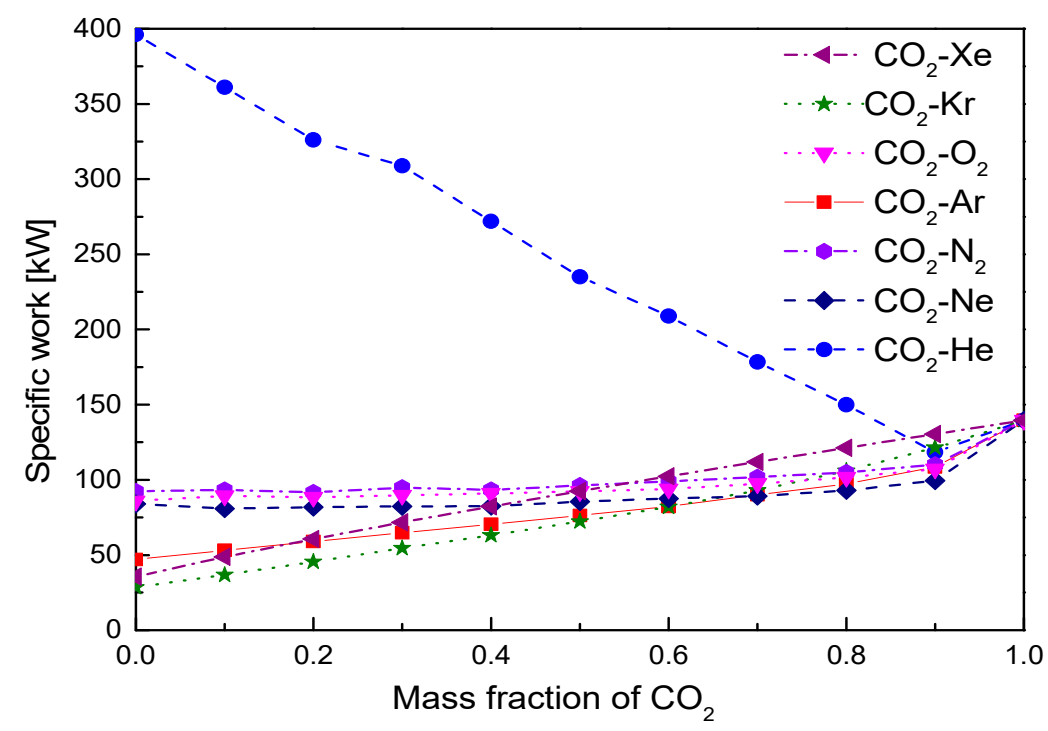

Figure 7. Specific work of mixtures at different mass fractions of $\mathrm{CO}_{2}$. 


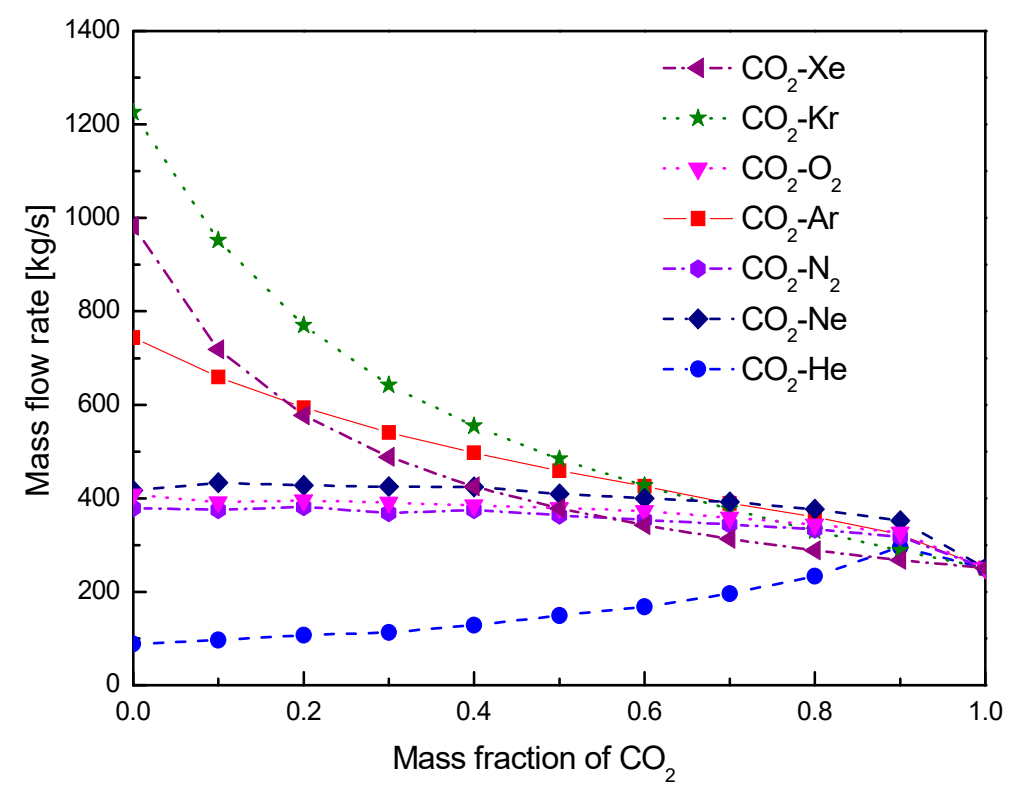

Figure 8. Mass flow rate of mixtures at different mass fractions of $\mathrm{CO}_{2}$.

Besides cycle efficiency, output work, and mass flow rate, amounts of heat input are also compared for different mixtures, as illustrated in Figure 9. Since the total net power output is fixed, the amount of absorbed heat is inversely proportional to cycle efficiency. Thus, the absorbed heat of $\mathrm{CO}_{2}-\mathrm{Xe}$ is the lowest. The value first decreases from $\mathrm{Xe}(64.95 \mathrm{MW})$ and then increase to $\mathrm{CO}_{2}(64.90 \mathrm{MW})$. As for the other mixtures, the absorbed heat gradually decreases to that of $\mathrm{CO}_{2}$. When mass fraction of $\mathrm{CO}_{2}$ is beyond 0.5, the heat input has the following order: $\mathrm{CO}_{2}-\mathrm{He}>\mathrm{CO}_{2}-\mathrm{Ne}>\mathrm{CO}_{2}-\mathrm{N}_{2}>\mathrm{CO}_{2}-\mathrm{O}_{2}>\mathrm{CO}_{2}-\mathrm{Ar}$ $>\mathrm{CO}_{2}-\mathrm{Kr}>\mathrm{CO}_{2}$-Xe. At high mass fraction of $\mathrm{CO}_{2}$, the curve of $\mathrm{CO}_{2}-\mathrm{N}_{2}$ almost coincides with that of $\mathrm{CO}_{2}-\mathrm{O}_{2}$, due to the fact that critical temperatures of $\mathrm{CO}_{2}-\mathrm{N}_{2}$ and $\mathrm{CO}_{2}-\mathrm{O}_{2}$ are close to each other.

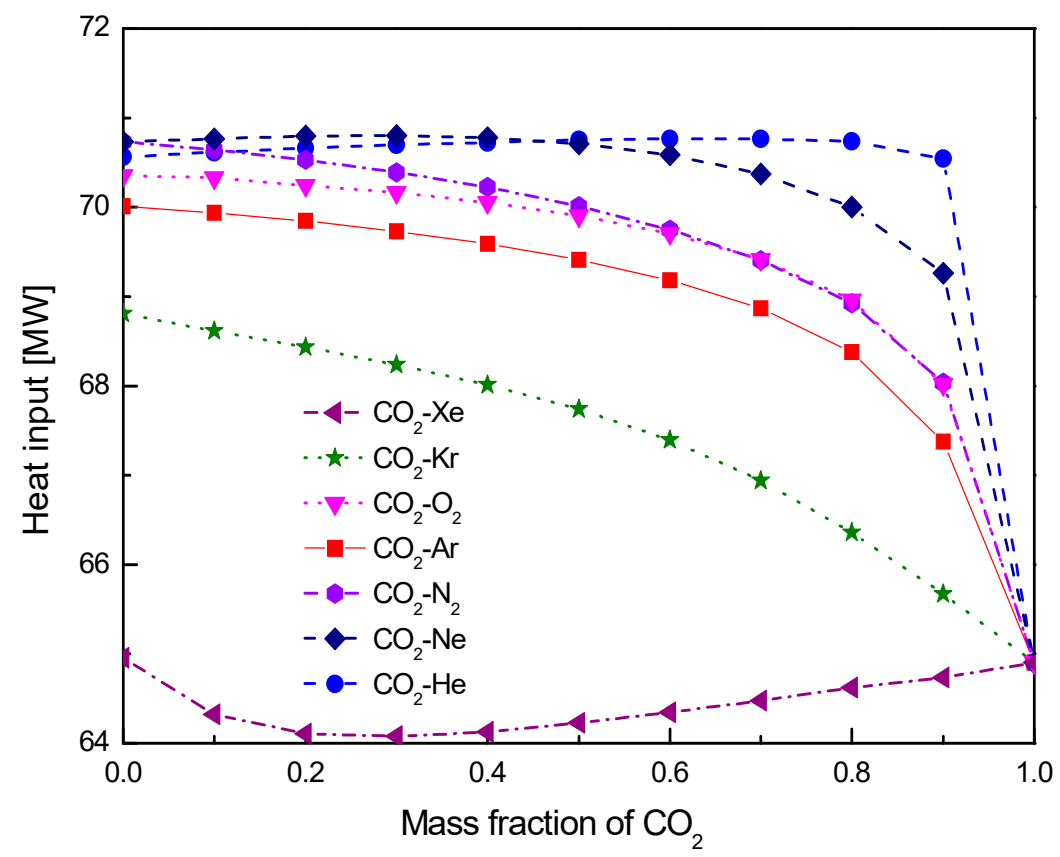

Figure 9. Heat input of mixtures at different mass fractions of $\mathrm{CO}_{2}$.

In the simulation, the high cycle pressure is fixed at $25 \mathrm{MPa}$ and pressure ratio is optimized for every mixture. Based on the determined pressure ratio, the low cycle pressure can be calculated. The corresponding variation curves are presented in Figure 10 for the considered mixtures. It can 
be observed that low cycle pressures for pure gases are higher than that of $\mathrm{CO}_{2}$. As the $\mathrm{CO}_{2}$ mass fraction increases, the pressure of $\mathrm{CO}_{2}$-Xe firstly shows a decrease and then a slowly increase, while other mixtures shows continue decrease of low pressure. For the considered mixtures, the highest curve of pressure is $\mathrm{CO}_{2}-\mathrm{He}$, while the lowest is $\mathrm{CO}_{2}-\mathrm{Xe}$. When the mass fraction is higher than 0.5, the low cycle pressure satisfies the following order: $\mathrm{CO}_{2}-\mathrm{He}>\mathrm{CO}_{2}-\mathrm{Ne}>\mathrm{CO}_{2}-\mathrm{Ar}>\mathrm{CO}_{2}-\mathrm{N}_{2}>\mathrm{CO}_{2}-\mathrm{O}_{2}$ $>\mathrm{CO}_{2}-\mathrm{Kr}>\mathrm{CO}_{2}-\mathrm{Xe}$. It should be noted that little difference exists for the pressure of $\mathrm{CO}_{2}-\mathrm{Ar}, \mathrm{CO}_{2}-\mathrm{N}_{2}$, and $\mathrm{CO}_{2}-\mathrm{O}_{2}$ at high mass fractions of $\mathrm{CO}_{2}$.

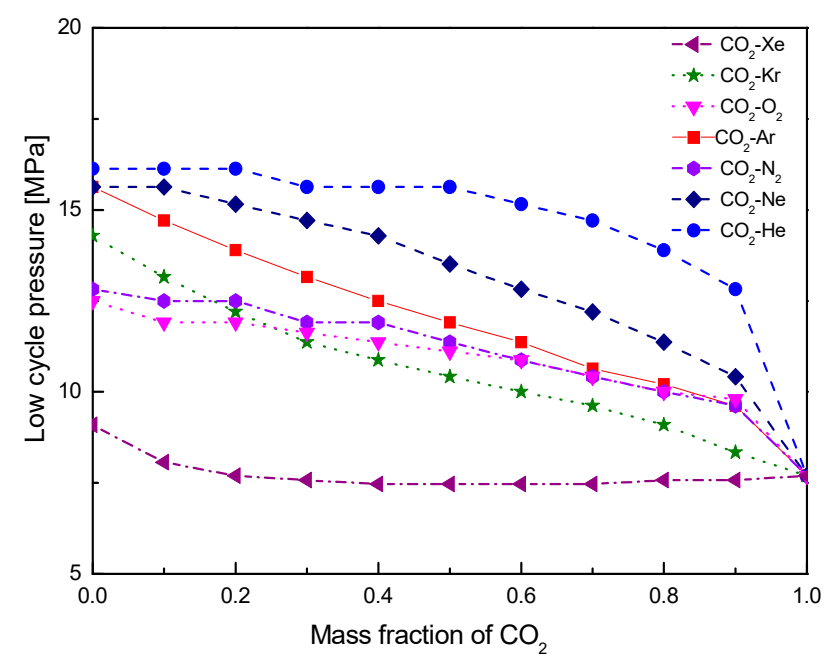

Figure 10. Low cycle pressure of mixtures at different mass fractions of $\mathrm{CO}_{2}$.

When the $\mathrm{S}-\mathrm{CO}_{2}$ power cycle is applied to solar energy, temperature increase of working fluid in the primary heater is an important index to evaluate the performance of solar power system. The larger the temperature increase, the greater the heat storage of molten salt [13]. Thus, Figure 11 presents the temperature increase of mixtures in the primary heater. It indicates that $\mathrm{CO}_{2}$-Xe has the highest temperature difference, followed by $\mathrm{CO}_{2}-\mathrm{Kr}$. For the $\mathrm{CO}_{2}-\mathrm{Xe}$ mixture, the temperature difference continues to decrease from $\mathrm{Xe}(235.24 \mathrm{~K})$ to $\mathrm{CO}_{2}(147.58 \mathrm{~K})$, while $\mathrm{CO}_{2}-\mathrm{Kr}$ firstly decrease from $\mathrm{Kr}(147.58 \mathrm{~K})$ and then increase to $\mathrm{CO}_{2}(147.58 \mathrm{~K})$ slowly. For other mixtures, the temperature difference continues to increase, as the $\mathrm{CO}_{2}$ mass fraction increases. At mass fraction larger than 0.5, the temperature difference has the order: $\mathrm{CO}_{2}-\mathrm{Xe}>\mathrm{CO}_{2}-\mathrm{Kr}>\mathrm{CO}_{2}-\mathrm{Ar}>\mathrm{CO}_{2}-\mathrm{N}_{2}>\mathrm{CO}_{2}-\mathrm{O}_{2}>\mathrm{CO}_{2}-\mathrm{Ne}$ $>\mathrm{CO}_{2}$-He. It should be noted that the curves of $\mathrm{CO}_{2}-\mathrm{Ar}, \mathrm{CO}_{2}-\mathrm{N}_{2}$, and $\mathrm{CO}_{2}-\mathrm{O}_{2}$ are close to each other.

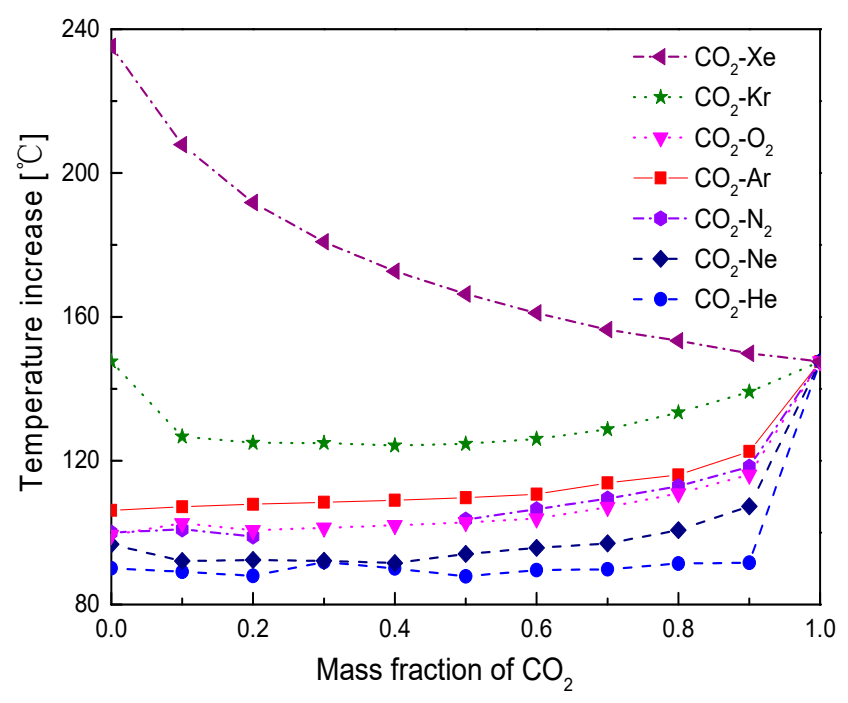

Figure 11. Temperature increase of mixtures in the primary heater. 


\subsection{Recuperator Analysis}

For the recompression cycle, the recuperator is a key component to improve cycle performance. Thus, the heat transfer and the required conductance of HTR and LTR are calculated for mixtures according to the conditions in Table 3. HTR heat and conductance are respectively presented in Figures 12 and 13. For the heat transfer in HTR, the heat of Xe (35.47 MW) is the lowest, then followed by $\mathrm{CO}_{2}(99.82 \mathrm{MW})$. The highest heat is for $\mathrm{He}(167.16 \mathrm{MW})$. With the increase of $\mathrm{CO}_{2}$ mass fraction, HTR heat of $\mathrm{CO}_{2}$-Xe increases, while other mixtures show downtrend of HTR heat in a whole. The irregularly small variation of HTR heat is because of nonlinear properties of mixtures. At different mass fractions of $\mathrm{CO}_{2}, \mathrm{CO}_{2}$-Xe has the lowest heat transfer, while heat of $\mathrm{CO}_{2}$-He is the highest. Compared with the heat input in Figure 9, HTR heat of mixtures is much higher except $\mathrm{CO}_{2}$-Xe at low mass fraction of $\mathrm{CO}_{2}$. As for the heat conductance of HTR. It is proportional to the transferred heat, as shown in Figure 13. It can be observed that the conductance variation of mixtures with $\mathrm{CO}_{2}$ mass fraction is similar to that of HTR heat. The lowest conductance is $1.8 \mathrm{MW} / \mathrm{K}$ for $\mathrm{Xe}$, while the highest value is $15.0 \mathrm{MW} / \mathrm{K}$ for He. $\mathrm{CO}_{2}$ has the conductance $3.26 \mathrm{MW} / \mathrm{K}$. In order to meet so much high heat transfer, it's thought that printed circuit heat exchanger (PCHE) has the potential to be applied, because of the great compactness and capability to withstand the high temperature and pressure. Furthermore, for the order of HTR heat and conductance in mixtures at high $\mathrm{CO}_{2}$ mass fraction, it has the following order: $\mathrm{CO}_{2}-\mathrm{He}>\mathrm{CO}_{2}-\mathrm{Ne}>\mathrm{CO}_{2}-\mathrm{O}_{2}>\mathrm{CO}_{2}-\mathrm{N}_{2}>\mathrm{CO}_{2}-\mathrm{Ar}>\mathrm{CO}_{2}-\mathrm{Kr}>\mathrm{CO}_{2}-\mathrm{Xe}$.

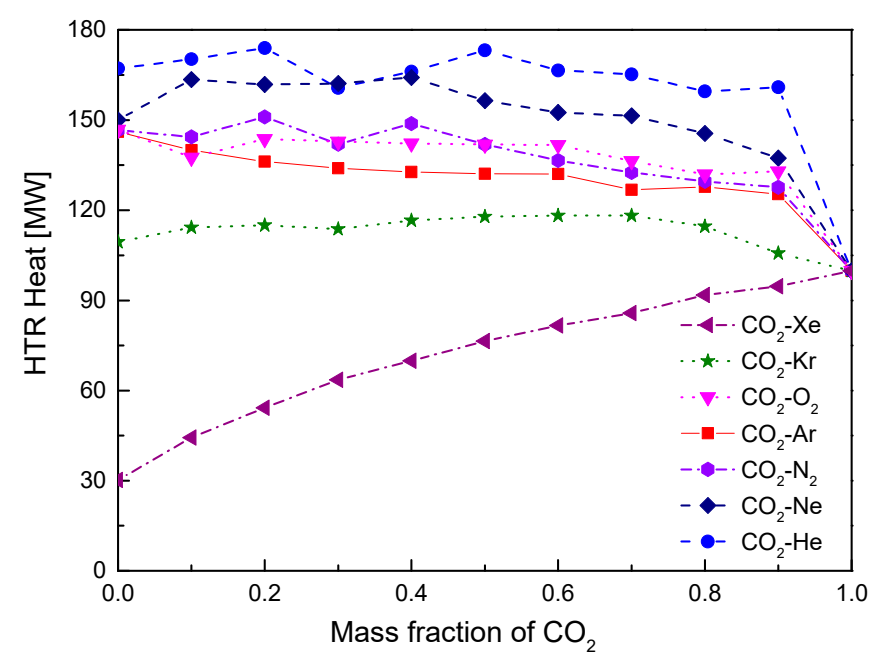

Figure 12. High-temperature recuperator (HTR) heat of mixtures at different mass fractions of $\mathrm{CO}_{2}$.

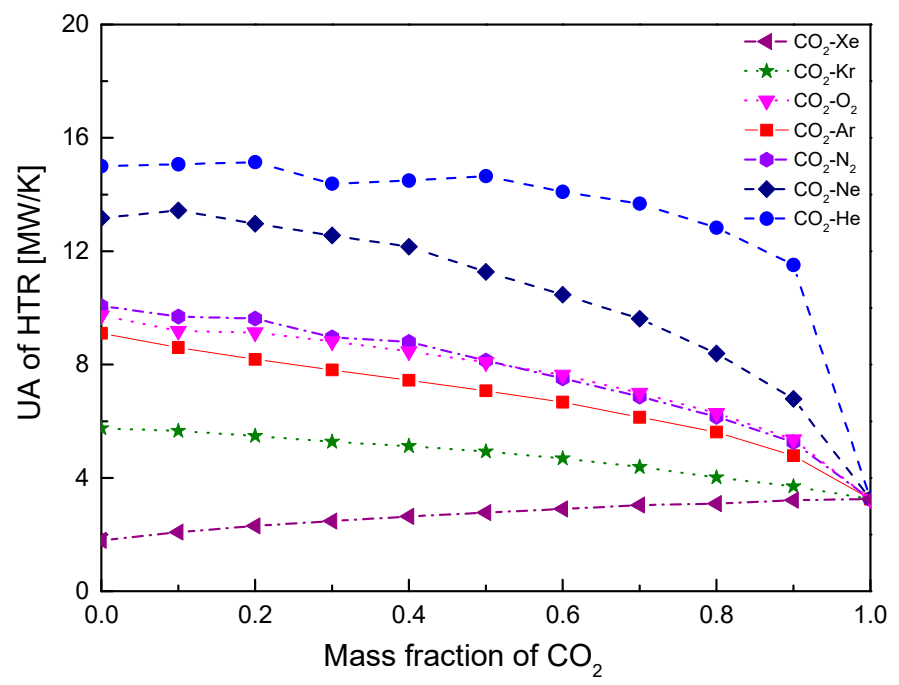

Figure 13. HTR conductance of mixtures at different mass fractions of $\mathrm{CO}_{2}$. 
In order to analyze the heat transfer difference between pure fluids and mixtures, temperature distributions in HTR are calculated for seven mixtures. The corresponding figures are presented in Supplementary Materials. Here, take $\mathrm{CO}_{2}-\mathrm{N}_{2}$ as an example, the temperature distributions for $\mathrm{CO}_{2}$, $\mathrm{CO}_{2}-\mathrm{N}_{2}(0.5 / 0.5)$ and $\mathrm{N}_{2}$ are illustrated in Figure 14. It can be seen that the transferred heats of $\mathrm{CO}_{2}-\mathrm{N}_{2}$ $(0.5 / 0.5)$ and $\mathrm{N}_{2}$ are much higher than that of $\mathrm{CO}_{2}$. In general, the pinch point of heat transfer locates at the cold end of HTR. The corresponding minimum temperature differences of $\mathrm{CO}_{2}, \mathrm{CO}_{2}-\mathrm{N}_{2}(0.5 / 0.5)$ and $\mathrm{N}_{2}$ are $10.88^{\circ} \mathrm{C}, 10.79^{\circ} \mathrm{C}$ and $10.76{ }^{\circ} \mathrm{C}$, respectively. Furthermore, for the considered mixtures, the calculated minimum temperature differences are provided in Supplementary Materials.

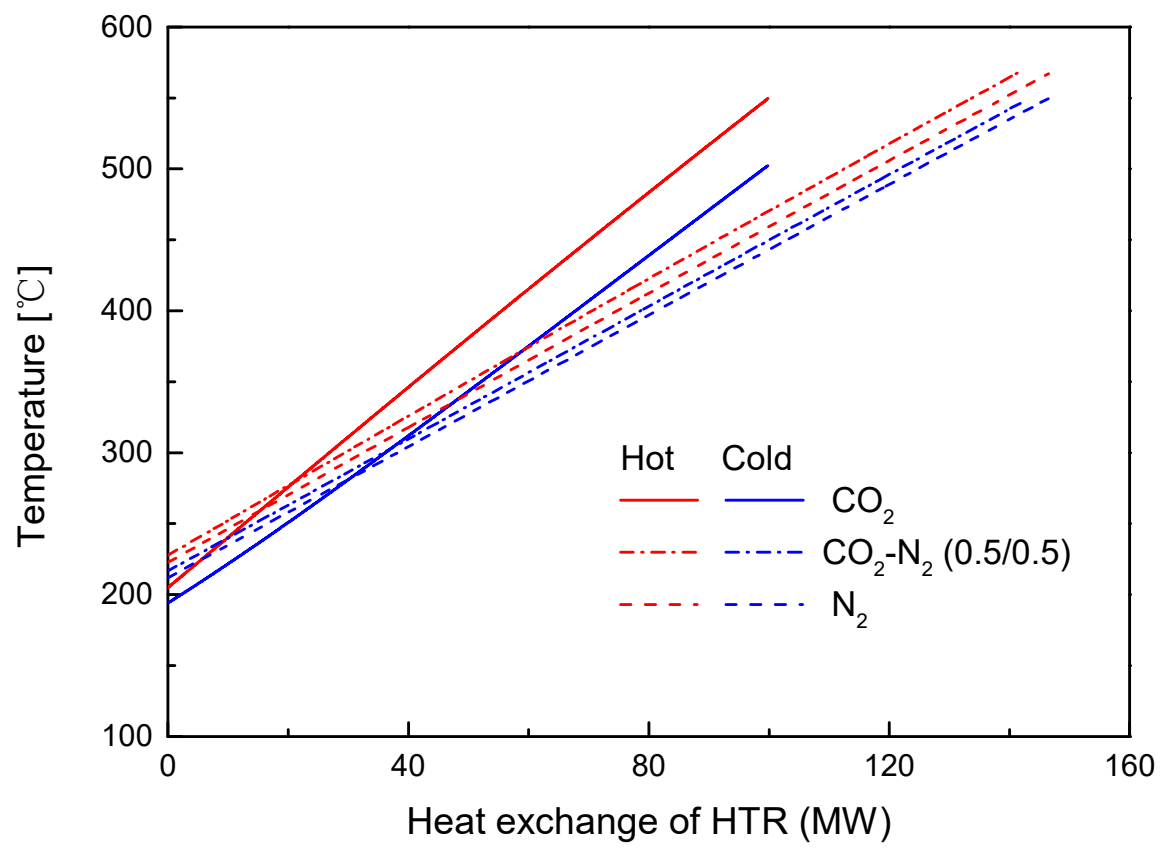

Figure 14. Temperature distributions of $\mathrm{CO}_{2}-\mathrm{N}_{2}$ in HTR.

Figure 15 illustrates the LTR heat of mixtures at different mass fractions of $\mathrm{CO}_{2}$. It can be seen that the LTR heat is far lower than those of heater and HTR, and the heat difference of LTR between different mixtures is also less than that presented in Figures 9 and 12. For the considered mixtures, $\mathrm{CO}_{2}$-Xe has the lowest LTR heat. As the $\mathrm{CO}_{2}$ mass fraction increases, LTR heat of the mixture gradually decrease from $\mathrm{Xe}(40.02 \mathrm{MW})$ to $\mathrm{CO}_{2}(38.06 \mathrm{MW})$. Being similar to $\mathrm{CO}_{2}-\mathrm{Xe}, \mathrm{CO}_{2}-\mathrm{Kr}$ also shows a slow decrease of LTR heat. However, for the other mixtures, when $\mathrm{CO}_{2}$ mass fraction is higher than 0.9, there exists a sharp decrease of LTR heat, as shown in Figure 15. As for the curves of LTR conductance, they are given in Figure 16. It indicates that although the LTR conductance of mixtures decreases with the increase of $\mathrm{CO}_{2}$ mass fraction, the variation range is smaller than that of HTR conductance. Special care should be given for $\mathrm{CO}_{2}$-Xe. When $\mathrm{CO}_{2}$ mass fraction is less than 0.2 , there is a sharp decrease of LTR conductance. Even if the heat transfer of LTR is the lowest for $\mathrm{CO}_{2}-\mathrm{Xe}$, the corresponding conductance is higher than that of other mixture at low $\mathrm{CO}_{2}$ mass fractions. This phenomenon can be explained by the matched heat capacities of the cold and hot sides. When the temperature match is improved, the logarithmic mean temperature difference will be reduced. On the other hand, at high mass fractions of $\mathrm{CO}_{2}$, mixtures have the following order of LTR heat and conductance: $\mathrm{CO}_{2}-\mathrm{He}>$ $\mathrm{CO}_{2}-\mathrm{Ne}>\mathrm{CO}_{2}-\mathrm{O}_{2}>\mathrm{CO}_{2}-\mathrm{N}_{2}>\mathrm{CO}_{2}-\mathrm{Ar}>\mathrm{CO}_{2}-\mathrm{Kr}>\mathrm{CO}_{2}$-Xe. It should be noted that the curves of $\mathrm{CO}_{2}-\mathrm{O}_{2}$ and $\mathrm{CO}_{2}-\mathrm{N}_{2}$ are close to each other. 


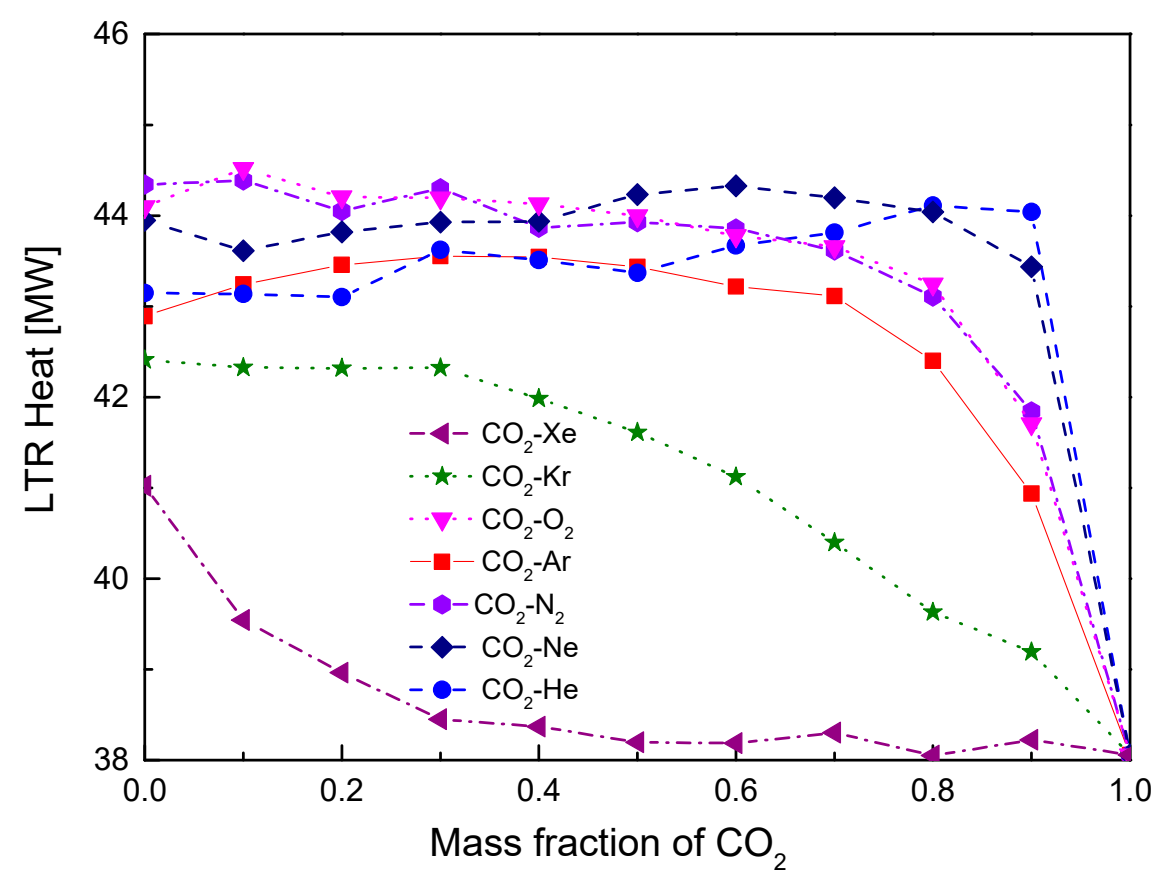

Figure 15. Low-temperature recuperator (LTR) heat of mixtures at different mass fractions of $\mathrm{CO}_{2}$.

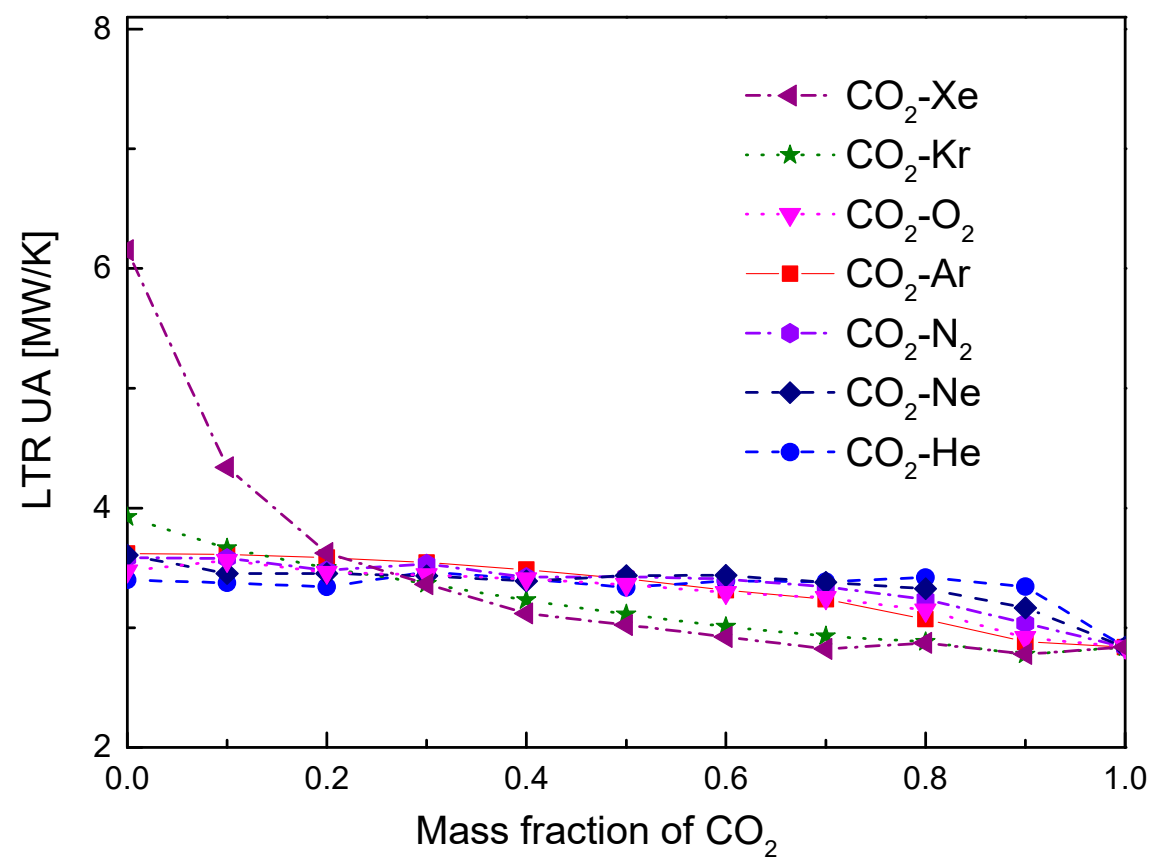

Figure 16. LTR conductance of mixtures at different mass fractions of $\mathrm{CO}_{2}$.

As for the temperature distributions in LTR, all figures are provided in Supplementary Materials for the considered mixtures. Figure 17 illustrates the temperature distributions of $\mathrm{CO}_{2}, \mathrm{CO}_{2}-\mathrm{N}_{2}$ $(0.5 / 0.5)$, and $\mathrm{N}_{2}$. It can be observed that although there are large differences of specific heat capacity between hot and cold streams at low temperatures, the differences of total heat capacity are greatly minimized by introducing splitting progress, so that the temperature mismatch in LTR is alleviated. For $\mathrm{CO}_{2}, \mathrm{CO}_{2}-\mathrm{N}_{2}(0.5 / 0.5)$ and $\mathrm{N}_{2}$, the minimum temperature differences are $10.89{ }^{\circ} \mathrm{C}, 10.80{ }^{\circ} \mathrm{C}$, and $10.76{ }^{\circ} \mathrm{C}$, respectively. Similarly, the minimum temperature differences of all mixtures are given in the Supplementary Materials. 


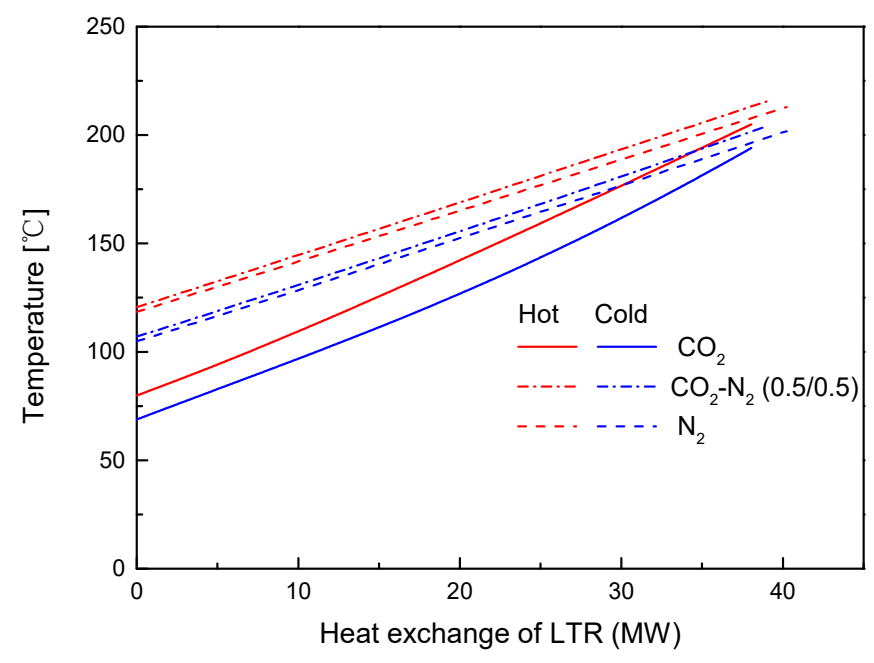

Figure 17. Temperature distributions of $\mathrm{CO}_{2}-\mathrm{N}_{2}$ in LTR.

In order to reduce the difference of specific heat capacity between the cold and hot sides in LTR, split ratio is optimized. The corresponding values are presented in Figure 18. It can be observed that split ratio of pure gas is higher than that of $\mathrm{CO}_{2}(0.63)$. The reason is that heat capacity difference decreases with the decrease of critical temperature, as illustrated in Table 2. The larger the heat capacity difference, the lower the split ratio. Therefore, $\mathrm{As} \mathrm{CO}_{2}$ mass fraction increases, split ratio decreases. Except $\mathrm{CO}_{2}-\mathrm{Xe}$ and $\mathrm{CO}_{2}-\mathrm{Kr}$, all mixtures show slow decrease firstly and then rapid decrease, especially for $\mathrm{CO}_{2}$-He. For these mixtures, the lowest curve is for $\mathrm{CO}_{2}-\mathrm{Xe}$, while $\mathrm{CO}_{2}-\mathrm{He}$ has the highest curve. The values of $\mathrm{CO}_{2}-\mathrm{He}$ are close to 1.0. Similarly, at high mass fractions of $\mathrm{CO}_{2}$, split ratio has the order: $\mathrm{CO}_{2}-\mathrm{He}>\mathrm{CO}_{2}-\mathrm{Ne}>\mathrm{CO}_{2}-\mathrm{N}_{2}>\mathrm{CO}_{2}-\mathrm{O}_{2}>\mathrm{CO}_{2}-\mathrm{Ar}>\mathrm{CO}_{2}-\mathrm{Kr}>\mathrm{CO}_{2}-\mathrm{Xe}$.

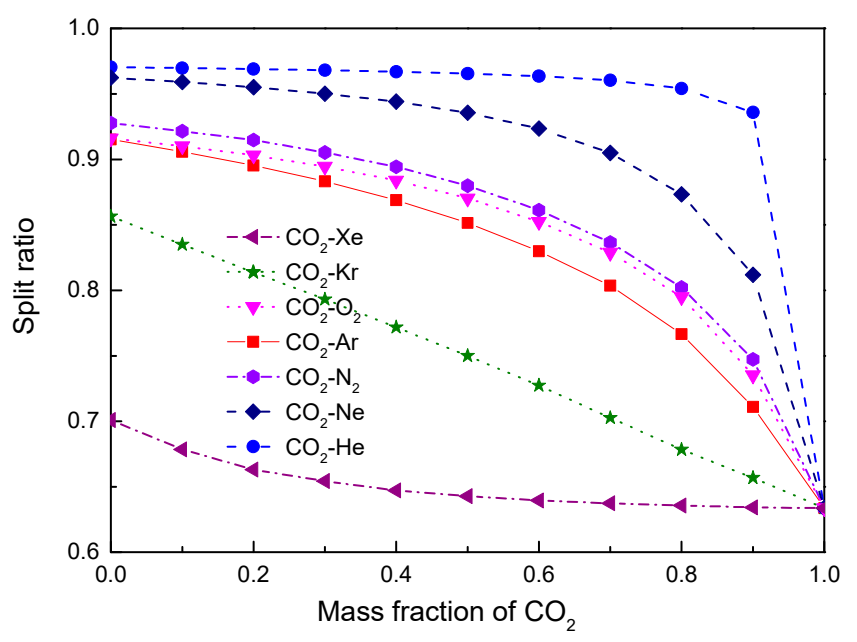

Figure 18. Split ratio of mixtures at different mass fractions of $\mathrm{CO}_{2}$.

\subsection{Effect of Compressor Inlet Temperature}

In order to investigate the effect of compressor inlet temperature, temperatures $T_{c 0}+1, T_{c 0}+10$, $T_{c 0}+20$, and $T_{c 0}+30$ are considered. Cycle performance and recuperator parameters of the considered mixtures are analyzed under the provided conditions in Table 3. Since the effect of compressor inlet temperature on the cycle parameters keeps the same for different mixtures, results of a typical mixture are presented in the following study. Considering that $\mathrm{N}_{2}$ is the most abundant gas in the air, it is highly possible to mix with $\mathrm{CO}_{2}$ so as to affect the performance of supercritical power cycle. Thus, $\mathrm{CO}_{2}-\mathrm{N}_{2}$ is selected. 
Figure 19 gives the cycle efficiency of $\mathrm{CO}_{2}-\mathrm{N}_{2}$ for the four temperatures. As the inlet temperature increases, cycle efficiency naturally decreases. For instance, at $T_{c 0}+1$ and $T_{c 0}+30, \mathrm{CO}_{2}$ has cycle efficiency 0.54 and 0.48 , respectively. Furthermore, with the increase of inlet temperature, the efficiency difference between $\mathrm{N}_{2}$ and $\mathrm{CO}_{2}$ decreases, so as to make the curve rise more smoothly, especially at the $\mathrm{CO}_{2}$ mass fraction beyond 0.9. As for the specific work, the increased temperature results into a greater power consumed by the main compressor. This makes the reduction of specific work, as shown in Figure 20. On the other hand, due to the increase of compressor inlet temperature, the inlet temperature of primary heater will accordingly increase. When the highest temperature is fixed at $650{ }^{\circ} \mathrm{C}$, the temperature difference in the primary heater will automatically decreases, as presented in Figure 21. Meanwhile, with the increase of compressor inlet temperature, the corresponding curve shows a slow increase from $\mathrm{N}_{2}$ to $\mathrm{CO}_{2}$, especially when $\mathrm{CO}_{2}$ mass fraction is higher than 0.9 .

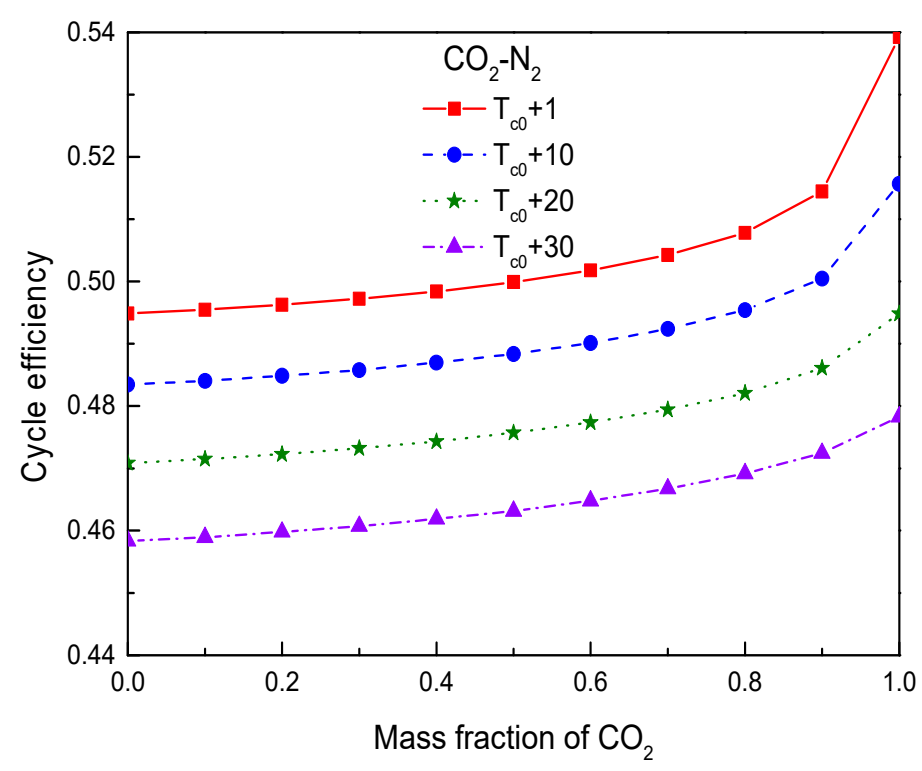

Figure 19. Cycle efficiency of $\mathrm{CO}_{2}-\mathrm{N}_{2}$ at different compressor inlet temperatures.

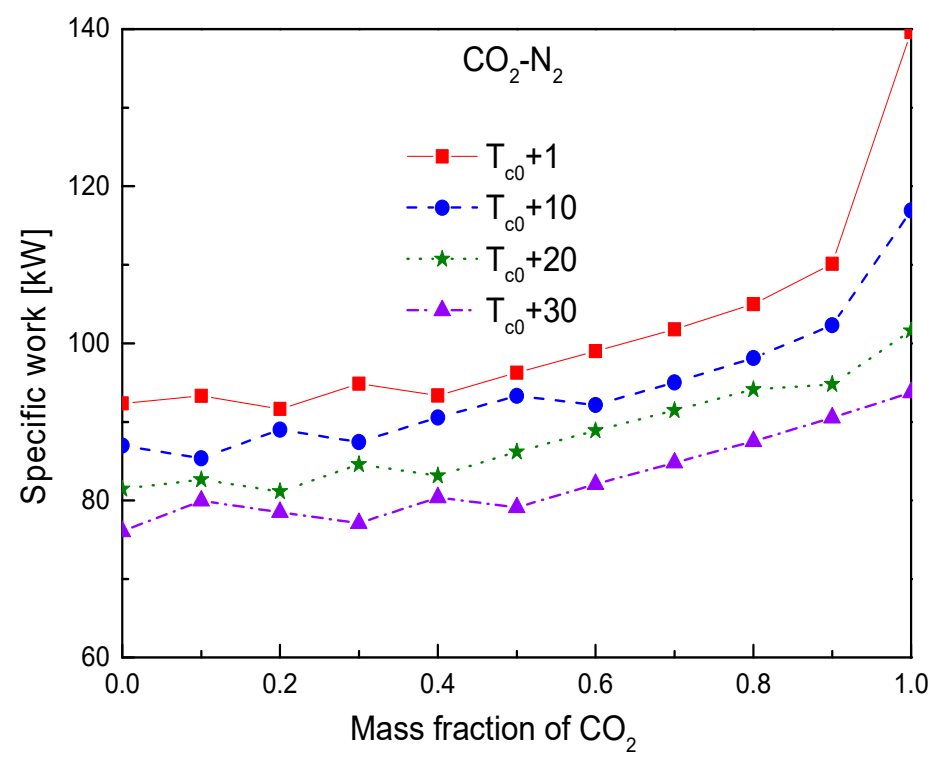

Figure 20. Specific work of $\mathrm{CO}_{2}-\mathrm{N}_{2}$ at different compressor inlet temperatures. 


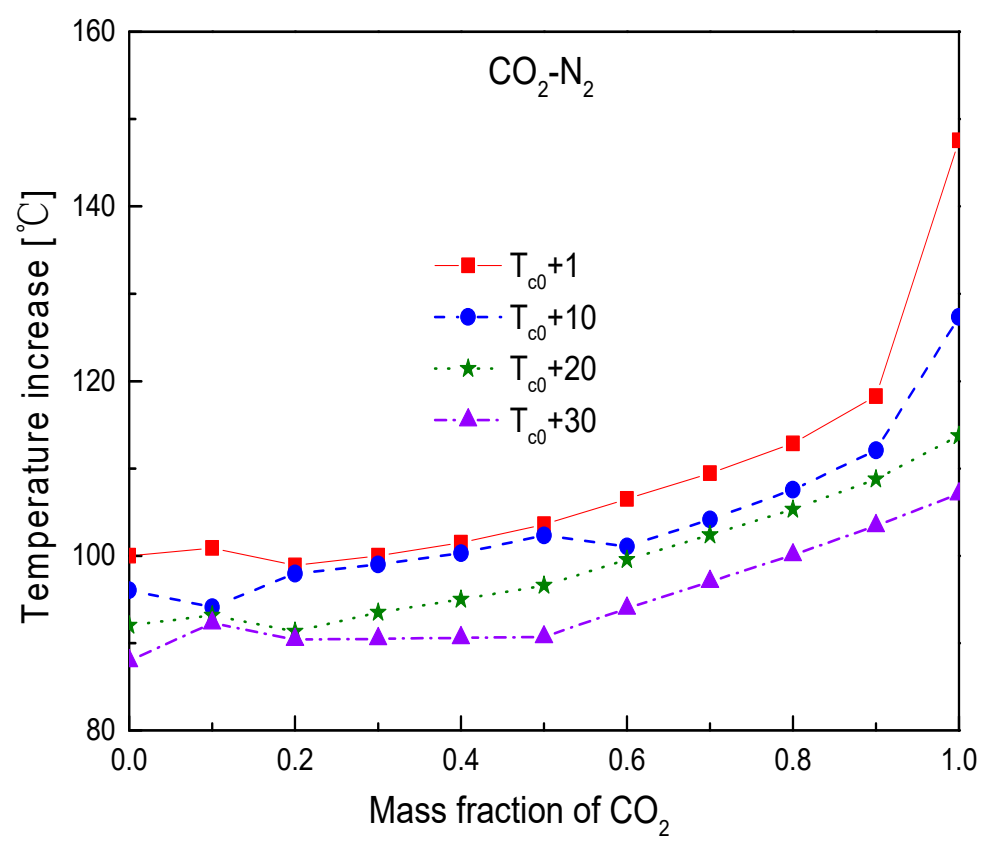

Figure 21. Temperature increase of $\mathrm{CO}_{2}-\mathrm{N}_{2}$ in the primary heater at different compressor inlet temperatures.

In the simulation, the total net power output is fixed. When the cycle efficiency decreases with the increase of compressor inlet temperature, the absorbed heat from the heat source will increase. Meanwhile, considering the temperature difference of mixture in the primary heater decreases, cycle mass flow rate is certain to increase to assure the required heat. This will result into more heat transfer in the recuperators. As presented in Figures 22 and 23, heat conductance of HTR and LTR increase with the increase of compressor inlet temperature. Furthermore, compared with the LTR conductance, the HTR conductance is more easily to be influenced by the increase of inlet temperature. Take $\mathrm{CO}_{2}$ as example, when inlet temperatures are $T_{c 0}+1$ and $T_{c 0}+30$, HTR conductance are 3.26 MW/K and 6.30 MW/K, while LTR has the conductance $2.84 \mathrm{MW} / \mathrm{K}$ and $3.54 \mathrm{MW} / \mathrm{K}$, respectively.

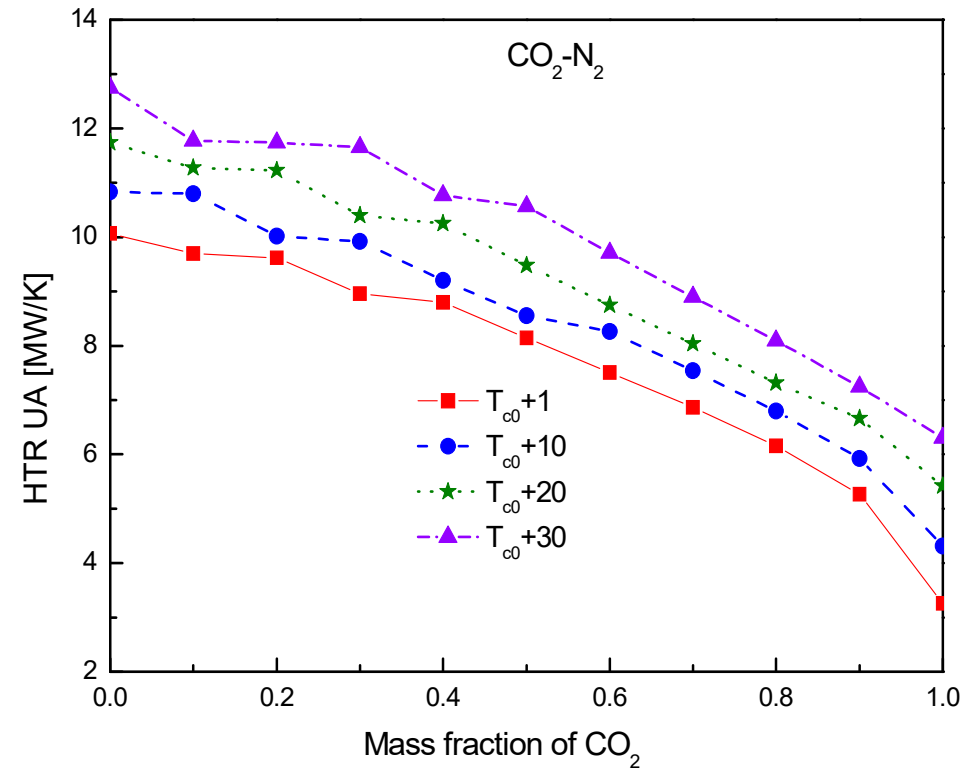

Figure 22. HTR conductance of $\mathrm{CO}_{2}-\mathrm{N} 2$ at different compressor inlet temperatures. 


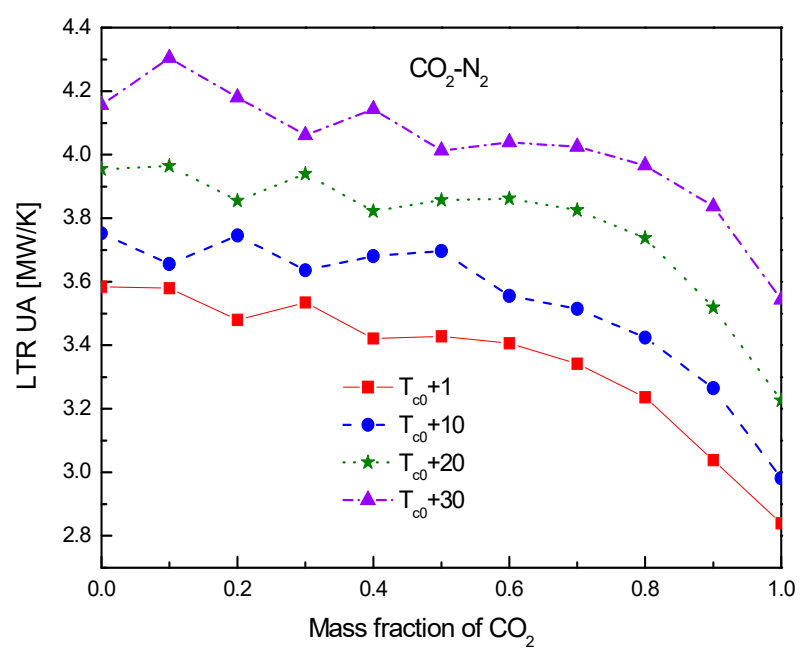

Figure 23. LTR conductance of $\mathrm{CO}_{2}-\mathrm{N}_{2}$ at different compressor inlet temperatures.

\section{Conclusions}

In the present study, a thermodynamic model is established for the recompression cycle. Seven types of $\mathrm{CO}_{2}$-based mixtures are employed to investigate the effect of mixtures on the supercritical power cycle from the perspective of thermodynamic analysis. Based on the optimized results, cycle performance and recuperators' heat transfer for different mixtures are comprehensively compared and analyzed at different mass factions of $\mathrm{CO}_{2}$.Therafter, in order to reveal the effect of compressor inlet temperature, cycle parameters of $\mathrm{CO}_{2}-\mathrm{N}_{2}$ are obtained and compared under four different temperatures. The main conclusions can be drawn as follows:

(1) Under the fixed compressor inlet temperature, except $\mathrm{CO}_{2}-\mathrm{Xe}$ and $\mathrm{CO}_{2}-\mathrm{He}$, cycle efficiency, specific work and temperature increase in the primary heater for other mixtures are generally lower than those for pure $\mathrm{CO}_{2}$. However, mass flow rate, heat input and low cycle pressure of these mixtures are generally higher than those of $\mathrm{CO}_{2}$. For the analyzed parameters, the order of mixtures almost coincides with the descending or ascending order of corresponding critical temperature. Performance curves of the considered mixtures locate between the curves of $\mathrm{CO}_{2}$-Xe and $\mathrm{CO}_{2}$-He. Furthermore, when the mass fraction is close to 1.0, there usually exists a sharp change of cycle performance for $\mathrm{CO}_{2}-\mathrm{He}, \mathrm{CO}_{2}-\mathrm{Ne}, \mathrm{CO}_{2}-\mathrm{N}_{2}, \mathrm{CO}_{2}-\mathrm{Ar}$, and $\mathrm{CO}_{2}-\mathrm{O}_{2}$.

(2) For the recuperators of recompression cycle, compared with the LTR heat, the HTR heat of mixtures is larger. Except $\mathrm{CO}_{2}-\mathrm{Xe}$, the transferred heat and the required conductance of HTR and LTR decrease with the increase of $\mathrm{CO}_{2}$ mass fraction. At high mass fractions of $\mathrm{CO}_{2}$, the considered mixtures satisfy the order: $\mathrm{CO}_{2}-\mathrm{He}>\mathrm{CO}_{2}-\mathrm{Ne}>\mathrm{CO}_{2}-\mathrm{O}_{2}>\mathrm{CO}_{2}-\mathrm{N}_{2}>\mathrm{CO}_{2}-\mathrm{Ar}>\mathrm{CO}_{2}-\mathrm{Kr}>\mathrm{CO}_{2}-\mathrm{Xe}$. As for the split ratio, the larger the heat capacity difference of mixtures between hot and cold sides in LTR, the lower the split ratio. All mixtures have higher split ratio than pure $\mathrm{CO}_{2}$. The order of split ratio for mixtures almost coincides with the above sequence. In general, the curves of $\mathrm{CO}_{2}-\mathrm{O}_{2}$ and $\mathrm{CO}_{2}-\mathrm{N}_{2}$ are close to each other.

(3) For the effect of compressor inlet temperature, the increase of inlet temperature will cause the decrease of cycle efficiency, specific work, and temperature difference in the primary heater. Heat conductance of recuperators will be increased. However, the obvious benefit of increasing inlet temperature is that it can increase the temperature difference between the working fluid and the cooling source, especially in hot or arid environments. This will greatly reduce the mass flow of cooling source and the required heat exchange area of gas cooler. Thus, how to determine the optimal inlet temperature of compressor is worth investigating by considering the thermodynamic and economic performances of working fluid simultaneously.

In engineering, $\mathrm{CO}_{2}$ is inevitably mixed with impurity gases, such as $\mathrm{N}_{2}$ or $\mathrm{O}_{2}$. This work is helpful to reveal the effect of these impurities on the performance of $\mathrm{S}-\mathrm{CO}_{2}$ Brayton cycle. Furthermore, 
for the utilization of $\mathrm{CO}_{2}$-based mixtures to improve the cycle performance, based on the property calculation of REFPROP, this study provides preliminary comparison results for seven types of mixtures under certain conditions. Therefore, in the future research, properties of $\mathrm{CO}_{2}$-based mixtures have to be deeply studied to ensure the application of mixtures. More investigations about the environmental impacts, costs, and experimental limitations should be performed for supercritical Brayton cycle with $\mathrm{CO}_{2}$-based mixtures by considering different driven heat sources.

Supplementary Materials: The following are available online at http://www.mdpi.com/1996-1073/13/7/1741/s1. Figure S1: Temperature distributions of $\mathrm{CO}_{2}$-Xe in a high-temperature recuperator (HTR); Figure S2: Temperature distributions of $\mathrm{CO}_{2}$-Xe in a low-temperature recuperator (LTR); Figure S3: Temperature distributions of $\mathrm{CO}_{2}-\mathrm{Kr}$ in HTR; Figure S4: Temperature distributions of $\mathrm{CO}_{2}-\mathrm{Kr}$ in LTR; Figure S5: Temperature distributions of $\mathrm{CO}_{2}-\mathrm{O}_{2}$ in HTR; Figure S6: Temperature distributions of $\mathrm{CO}_{2}-\mathrm{O}_{2}$ in LTR; Figure S7: Temperature distributions of $\mathrm{CO}_{2}-\mathrm{Ar}$ in HTR; Figure S8: Temperature distributions of $\mathrm{CO}_{2}-\mathrm{Ar}$ in LTR; Figure S9: Temperature distributions of $\mathrm{CO}_{2}-\mathrm{N}_{2}$ in HTR; Figure S10: Temperature distributions of $\mathrm{CO}_{2}-\mathrm{N}_{2}$ in LTR; Figure S11: Temperature distributions of $\mathrm{CO}_{2}-$ Ne in HTR; Figure S12: Temperature distributions of $\mathrm{CO}_{2}$ - Ne in LTR; Figure S13: Temperature distributions of $\mathrm{CO}_{2}$ - He in HTR; Figure S14: Temperature distributions of $\mathrm{CO}_{2}$ - He in LTR; Figure S15: Minimum temperature differences of considered mixtures in HTR; Figure S16: Minimum temperature differences of considered mixtures in LTR. According to the given conditions, cycle parameters are completely calculated for the seven mixtures. The corresponding data are listed in Excel. Furthermore, for these mixtures, temperature distributions in the HTR and LTR are also presented in the form of figure.

Author Contributions: Writing—original draft preparation, A.Y.; Conceptualization and writing—review and editing, W.S.; Funding acquisition, L.Z.; Methodology, X.L.; investigation, N.Z. All authors have read and agreed to the published version of the manuscript.

Funding: This work is supported by the program "Researches on the fundamental theory for the optimization and operation of supercritical $\mathrm{CO}_{2}$ power cycle" from China Three Gorges Corporation, grant number 202003024.

Acknowledgments: The authors gratefully acknowledge the support from the School of Energy Science and Engineering, Central South University.

Conflicts of Interest: The authors declare no conflict of interest. 


\section{Nomenclature}

\begin{tabular}{|c|c|}
\hline \multicolumn{2}{|l|}{ Symbols } \\
\hline $\mathrm{C}$ & Heat Capacity, $\mathrm{KJ} /(\mathrm{kg} \cdot \mathrm{K})$ \\
\hline $\mathrm{D}$ & Density, $\mathrm{kg} / \mathrm{m}^{3}$ \\
\hline HTR & High temperature recuperator \\
\hline HPT & High pressure turbine \\
\hline$h$ & Enthalpy, kJ/kg \\
\hline LTR & Low temperature recuperator \\
\hline LPT & Low pressure turbine \\
\hline$m$ & Mass flow rate, $\mathrm{kg} / \mathrm{s}$ \\
\hline M & Molar mass, $\mathrm{g} / \mathrm{mol}$ \\
\hline $\mathrm{P}$ & Pressure, $\mathrm{MPa}$ \\
\hline PPTD & Pinch point temperature difference, ${ }^{\circ} \mathrm{C}$ \\
\hline$Q$ & Heat, kJ \\
\hline $\mathrm{S}-\mathrm{CO}_{2}$ & Supercritical $\mathrm{CO}_{2}$ \\
\hline SFR & Sodium-cooled fast reactor \\
\hline$S R$ & Split ratio \\
\hline$T$ & Temperature, K \\
\hline$W$ & Work, kW \\
\hline UA & Heat conductance, $\mathrm{MW} / \mathrm{K}$ \\
\hline \multicolumn{2}{|l|}{ Greeks } \\
\hline$\varepsilon$ & Effectiveness of recuperator \\
\hline$\eta$ & Efficiency \\
\hline$\Delta$ & Difference \\
\hline \multicolumn{2}{|l|}{ Subscripts } \\
\hline $1,2, \ldots 10$ & State points of recompression cycle \\
\hline$b$ & Boiling temperature \\
\hline$c$ & Cycle/critical temperature \\
\hline$c_{0}$ & Critical temperature of $\mathrm{CO}_{2}$ \\
\hline HPT & High pressure turbine \\
\hline HTR & High temperature recuperator \\
\hline LPT & Low pressure turbine \\
\hline LTR & Low temperature recuperator \\
\hline MC & Main Compressor \\
\hline net & Net work \\
\hline$p$ & Heat capacity \\
\hline ph & Primary heater \\
\hline $\mathrm{RC}$ & Recompressor \\
\hline$r h$ & Reheater \\
\hline$s$ & Equal entropy \\
\hline
\end{tabular}

\section{References}

1. Dudley, B. BP statistical review of world energy. In Proceedings of the World Petroleum Congress, London, UK, 30 September 2019.

2. Wang, J.; Lund, P.D.; Zhu, H. Thermal performance analysis of a direct-heated recompression supercritical carbon dioxide Brayton cycle using solar concentrators. Energies 2019, 12, 4358. [CrossRef]

3. Manente, G.; Costa, M. On the Conceptual Design of Novel Supercritical $\mathrm{CO}_{2}$ Power Cycles for Waste Heat Recovery. Energies 2020, 13, 370. [CrossRef]

4. Liu, Y.; Wang, Y.; Huang, D. Supercritical $\mathrm{CO}_{2}$ Brayton cycle: A state-of-the-art review. Energy 2019, 189, 115900. [CrossRef]

5. Wang, X.R.; Li, X.X.; Li, Q.B.; Liu, L.; Liu, C. Performance of a solar thermal power plant with direct air-cooled supercritical carbon dioxide Brayton cycle under off-design conditions. Appl. Energy 2020, 261, 114359. [CrossRef]

6. Ma, T.; Li, M.J.; Xu, J.L.; Cao, F. Thermodynamic analysis and performance prediction on dynamic response characteristic of PCHE in $1000 \mathrm{MW} \mathrm{S-CO} 2$ coal fired power plant. Energy 2019, 175, 123-138. [CrossRef]

7. Yu, H.; Hartanto, D.; Moon, J.; Kim, Y. A conceptual study of a supercritical $\mathrm{CO}_{2}$-cooled Micro Modular Reactor. Energies 2015, 8, 13938-13952. [CrossRef]

8. Zhang, D.; Wang, Y.; Xie, Y. Investigation into off-design performance of a s- $\mathrm{CO}_{2}$ turbine based on concentrated Solar Power. Energies 2018, 11, 3014. [CrossRef] 
9. Ma, Y.G.; Morosuk, T.; Luo, J.; Liu, M.; Liu, J. Superstructure design and optimization on supercritical carbon dioxide cycle for application in concentrated solar power plant. Energy Convers. Manag. 2020, 206, 112290. [CrossRef]

10. Crespi, F.; Gavagnin, G.; Sánchez, D.; Martinez, G.S. Supercritical carbon dioxide cycles for power generation: A review. Appl. Energy 2017, 195, 152-183. [CrossRef]

11. Linares, J.I.; Montes, M.J.; Cantizano, A.; Sanchez, C. A novel supercritical $\mathrm{CO}_{2}$ recompression Brayton power cycle for power tower concentrating solar plants. Appl. Energy 2020, 263, 114644. [CrossRef]

12. Crespi, F.; Sánchez, D.; Rodríguez, J.M.; Gavagnin, G. A thermo-economic methodology to select sCO $\mathrm{S}_{2}$ power cycles for CSP applications. RENEW Energy 2020, 147, 2905-2912. [CrossRef]

13. Wang, K.; He, Y.L.; Zhu, H.H. Integration between supercritical $\mathrm{CO}_{2}$ Brayton cycles and molten salt solar power towers: A review and a comprehensive comparison of different cycle layouts. Appl. Energy 2017, 195, 819-836. [CrossRef]

14. Turchi, C.S.; Ma, Z.; Neises, T.W.; Wagner, M.J. Thermodynamic study of advanced supercritical carbon dioxide power cycles for concentrating solar power systems. J. Sol. Energy Eng. 2013, 135, 041007. [CrossRef]

15. Zhu, H.H.; Wang, K.; He, Y.L. Thermodynamic analysis and comparison for different direct-heated supercritical $\mathrm{CO}_{2}$ Brayton cycles integrated into a solar thermal power tower system. Energy 2017, 140, 144-157. [CrossRef]

16. Moisseytsev, A.; Sienicki, J.J. Investigation of alternative layouts for the super-critical carbon dioxide Brayton cycle for a sodium-cooled fast reactor. Nucl. Eng. Des. 2009, 239, 1362-1371. [CrossRef]

17. Kulhánek, M.; Dostal, V. Thermodynamic analysis and comparison of supercritical carbon dioxide cycles. In Proceedings of the Supercritical CO 2 Power Cycle Symposium, Boulder, CO, USA, 24-25 May 2011.

18. Wright, S.A.; Conboy, T.M.; Ames, D.E.; Lewis, T.G. $\mathrm{CO}_{2}$-Based Mixtures as Working Fluids for Geothermal Turbines; AC04-94AL85000; Sandia National Laboratories: Livermore, CA, USA, January 2012.

19. Jeong, W.S.; Jeong, Y.H. Performance of supercritical Brayton cycle using $\mathrm{CO}_{2}$-based binary mixture at varying critical points for SFR applications. Nucl. Eng. Des. 2013, 262, 12-20. [CrossRef]

20. Jeong, W.S.; Lee, J.I.; Jeong, Y.H. Potential improvements of supercritical recompression $\mathrm{CO}_{2}$ Brayton cycle by mixing other gases for power conversion system of a SFR. Nucl. Eng. Des. 2011, 241, 2128-2137. [CrossRef]

21. Hu, L.; Chen, D.; Huang, Y.; Li, L.; Cao, Y.; Yuan, D.; Wang, J.; Pan, L. Investigation on the performance of the supercritical Brayton cycle with $\mathrm{CO}_{2}$-based binary mixture as working fluid for an energy transportation system of a nuclear reactor. Energy 2015, 89, 874-886. [CrossRef]

22. Baik, S.; Lee, J.I. Preliminary study of supercritical $\mathrm{CO}_{2}$ mixed with gases for power cycle in warm environments. In Proceedings of the ASME Turbo Expo; ASME Digital Library: New York, NY, USA, 2018.

23. Guo, J.Q.; Li, M.J.; Xu, J.L.; Yan, J.; Wang, K. Thermodynamic performance analysis of different supercritical Brayton cycles using $\mathrm{CO}_{2}$-based binary mixtures in the molten salt solar power tower systems. Energy 2019, 173, 785-798. [CrossRef]

24. Vesely, L.; Dostal, V.; Stepanek, J. Effect of gaseous admixtures on cycles with supercritical carbon dioxide. In Proceedings of the ASME Turbo Expo; ASME Digital Library: New York, NY, USA, 2016.

25. Vesely, L.; Manikantachari, K.R.V.; Vasu, S.; Kapat, J.; Dostal, V.; Martin, S. Effect of impurities on compressor and cooler in supercritical $\mathrm{CO}_{2}$ cycles. J. Energy Resour. Technol. 2019, 141, 012003. [CrossRef]

26. Ma, Y.; Liu, M.; Yan, J.; Liu, J. Performance investigation of a novel closed Brayton cycle using supercritical $\mathrm{CO}_{2}$-based mixture as working fluid integrated with a LiBr absorption chiller. Appl. Therm. Eng. 2018, 141, 531-547. [CrossRef]

27. Lemmon, E.W.; Bell, I.H.; Huber, M.L.; McLinden, M.O. NIST Standard Reference Database 23: Reference Fluid Thermodynamic and Transport Properties-REFPROP; Version 10.0; National Institute of Standards and Technology, Standard Reference Data Program: Gaithersburg, MD, USA, 2018.

28. Neises, T.; Turchi, C. A comparison of supercritical carbon dioxide power cycle configurations with an emphasis on CSP applications. Energy Procedia 2014, 49, 1187-1196. [CrossRef]

(C) 2020 by the authors. Licensee MDPI, Basel, Switzerland. This article is an open access article distributed under the terms and conditions of the Creative Commons Attribution (CC BY) license (http://creativecommons.org/licenses/by/4.0/). 